\title{
The effect of organic compounds on the growth rate of cloud droplets in marine and forest settings
}

\author{
N. C. Shantz ${ }^{1}$, W. R. Leaitch ${ }^{2}$, L. Phinney ${ }^{3}$, M. Mozurkewich ${ }^{4}$, and D. Toom-Sauntry ${ }^{2}$ \\ ${ }^{1}$ Department of Chemistry, University of Toronto, Toronto, Ontario, Canada \\ ${ }^{2}$ Climate Research Division, Environment Canada, Toronto, Ontario, Canada \\ ${ }^{3}$ Air Quality Sciences, Meteorological Service of Canada, Dartmouth, Nova Scotia, Canada \\ ${ }^{4}$ Department of Chemistry and Centre for Atmospheric Chemistry, York University, Toronto, Ontario, Canada
}

Received: 17 March 2008 - Published in Atmos. Chem. Phys. Discuss.: 25 April 2008

Revised: 30 July 2008 - Accepted: 21 August 2008 - Published: 13 October 2008

\begin{abstract}
Organic matter represents an important fraction of the fine particle aerosol, yet our knowledge of the roles of organics in the activation of aerosol particles into cloud droplets is poor. A cloud condensation nucleus (CCN) counter is used to examine the relative growth rates of cloud droplets for case studies from field measurements on the North Pacific Ocean and in a coniferous forest. A model of the condensational growth of water droplets, on particles dissolving according to their solubility in water, is used to simulate the initial scattering of the droplets as they grow in the CCN counter. Simulations of the growth rates of fine particles sampled in the marine boundary layer of the North Pacific Ocean shows no evidence of natural marine organic material contributing to the $\mathrm{CCN}$ water uptake but there is an indication of an influence from organics from diesel ship emissions on the size distribution of sulphate and the ability of these particles to act as CCN. Simulations of the observations of water uptake on biogenic organic aerosol particles sampled in a coniferous forest indicate an impact of the organic on the water uptake rates, but one that is still smaller than that of pure sulphate. The existence of organics becomes important in determining the water uptake as the organic mass increases relative to sulphate. The values of the organic component of the hygroscopicity parameter $\kappa$ that describes the $\mathrm{CCN}$ activity were found to be negligible for the marine particles and 0.02-0.05 for the forest particles.
\end{abstract}

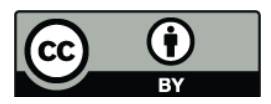

Correspondence to: N. C. Shantz (nicole.shantz@ec.gc.ca)

\section{Introduction}

One of the largest uncertainties in determining the human impact on the global climate is the effect of aerosol particles on clouds or the indirect effect (IPCC, 2007). Atmospheric aerosol particles have varying abilities to nucleate cloud droplets depending on the size and composition of the particles. Historically, it was believed that primarily highly soluble inorganic species, such as sulphate and sea salt, contributed to cloud droplet growth. More recently, it has become apparent that organics are a significant component of the atmospheric aerosol, but we lack sufficient knowledge about how organic compounds act as cloud condensation nuclei $(\mathrm{CCN})$, and this contributes to the large uncertainty in the indirect effect (IPCC, 2007). There may be thousands of individual species comprising the organic aerosol fraction and characterization of the organic constituents in the atmosphere has only scratched the surface (e.g. Alves et al., 2001; Carvalho et al., 2003; Gao et al., 2003; Graham et al., 2003; Yu et al., 2005). Because the known organic compounds range from soluble to insoluble (Saxena and Hildemann, 1996), the question of how the particulate organic contributes to cloud droplet growth is more difficult.

The complexity of the organic aerosol has led some, when examining aerosol-CCN and aerosol cloud droplet closure, to assume that the entire aerosol mass was inorganics such as sulphate. In some cases, this assumption has led to reasonable agreement between the observed number of cloud droplets or CCN (e.g. Conant et al., 2004; VanReken et al., 2003). In other cases, the agreement was relatively poor and a lack of information about organics is one of the

Published by Copernicus Publications on behalf of the European Geosciences Union. 
explanations (e.g. Snider et al., 2003). Some found that the inorganic mass present during the field measurements accounted for the majority of the water uptake or CCN activity and the organic mass did not contribute substantially to the water uptake; thus the organic could be assumed to be insoluble (Broekhuizen et al., 2006; Cantrell et al., 2001; Fountoukis et al., 2007; Lowenthal et al., 2003; Medina et al., 2007; Roberts et al., 2002). Chang et al. (2007) found specific times of high organic mass during a field study when the insoluble organic assumption led to an underestimation in the number of $\mathrm{CCN}$, and it was necessary to assume that water uptake by the organic was significant. Organics have been shown to contribute to water uptake at relative humidities less than 100\% (e.g. Dick, 2000; Gysel et al., 2004), and Kreidenweis et al. (2006) suggest that treating the slightly soluble component of the aerosol as either fully soluble or fully insoluble may be the reason why closure has not always been achieved for polluted air in field measurements.

Overall, organic particles tend to be less soluble than the major inorganic compounds in the atmospheric aerosol, which may lead to delayed particle activation (Shantz et al., 2003; Shulman et al., 1996). Organic compounds may also inhibit the condensation of water (e.g. Cantrell et al., 2001; Feingold and Chuang, 2002). On the other hand, organics may decrease the surface tension of a droplet, tending to increase its ability to take up water (Anttila and Kerminen, 2002; Ervens et al., 2004; Facchini et al., 1999; Mircea et al., 2002; Shulman et al., 1996). This surface tension effect could potentially counteract the delayed activation imposed by reduced particle solubility (Shulman et al., 1996). However, the effect of surface active organics on water uptake is still an unknown (Abbatt et al., 2005; Bilde and Svenningsson, 2004).

Laboratory studies of the effect of organics on cloud droplet activation have shown that water-soluble organics contribute to $\mathrm{CCN}$ activity, insoluble organics do not and slightly soluble organics have a range of cloud-forming capabilities (Abbatt et al., 2005; Broekhuizen et al., 2004; Corrigan and Novakov, 1999; Cruz and Pandis, 1997; Giebl et al., 2002; Hartz et al., 2006; Henning et al., 2005; Hori et al., 2003; Kumar et al., 2003; Prenni et al., 2001; Raymond and Pandis, 2002; Shantz et al., 2003). The addition of even a few percent of inorganic material (by mass) to a mostly insoluble organic particle can have a large impact on the CCN activation (Abbatt et al., 2005; Bilde and Svenningsson, 2004; Broekhuizen et al., 2004; Lohmann et al., 2004; Raymond and Pandis, 2003).

Results from modelling studies of the effects of organics solubility on the formation of cloud droplets have varied. Abdul-Razzak and Ghan (2005) found that in mixtures of slightly soluble organics with inorganics, the organics can be considered fully soluble yet Ervens et al. (2004) found that including low solubility organics decreased the number of $\mathrm{CCN}$ relative to a fully soluble case. Mircea et al. (2005) showed that with a situation with a high organic fraction, knowledge of the chemical composition (and thus the solubility) of the water-soluble component of the aerosol is needed.

The delay in the growth of cloud droplets formed on organic particles due to reduced solubility observed in a laboratory and modelling study can have a significant effect on the ability of particles to activate in clouds in the atmosphere (Shantz et al., 2003). The effect of the slow dissolution of organic compounds can be more profound in a rising air parcel where growing droplets (and the subsequent water depletion) affect the cloud supersaturation than in a $\mathrm{CCNc}$, where the supersaturation is held constant.

The work presented here extends the approach of Shantz et al. (2003) to field observations. The initial growth of aerosols as they activate into cloud droplets is examined using measurements from two field projects, one sampling from a ship on the North Pacific Ocean as part of the Canadian Surface Ocean and Lower Atmosphere Study (C-SOLAS) and one sampling in Golden Ears Provincial Park on the west coast of Canada. These sites provide strong contrasts, a marine environment with the aerosol mass dominated by sulphate (Phinney et al., 2006) and a forest site with a small urban influence and dominated by organic aerosol (Shantz et al., 2004).

A model that treats changes in droplet growth with respect to time (including the dissolution of organics as water is added by condensation) and the Mie scattering off of these droplets is used to simulate the $\mathrm{CCN}$ measurements and to study the differences of the two contrasting aerosol regimes on the nucleation of cloud droplets. This kinetic approach simulates changes from time step to time step driven by changes in the chemical equilibrium of each droplet as water condenses. Also, because there is a need to simplify this process for large-scale models and because it is difficult to characterize the water activity of organic aerosols due to their complexity and limited information about their chemical compositions, a single hygroscopicity parameter that considers both hygroscopic and CCN activity ( $\kappa$ : Petters and Kreidenweis, 2007) is used here in addition to the above approach. This holds the hygroscopicity parameter constant and therefore is an equilibrium approach that does not account for dissolution.

\section{Instrumentation}

\subsection{Particle size distributions}

Size distributions of particles in the geometric diameter range $0.01-0.4 \mu \mathrm{m}$ were measured with a Scanning Mobility Particle Sizer (SMPS) comprised of a TSI 3071 Electrostatic Classifier and a TSI 3025 Ultrafine Condensation Particle Counter. Larger particle size distributions were measured using an optical particle counter, a PMS Passive Cavity Aerosol Spectrometer Probe (PCASP). Both the SMPS and PCASP 
are used in the two field projects, the C-SOLAS study and the Golden Ears study (see Phinney et al., 2006 and Shantz et al., 2004, respectively, for further details).

\subsection{Particle chemical constituents}

During the C-SOLAS study, an Aerodyne Quadrupole Aerosol Mass Spectrometer (Q-AMS, see Jayne et al., 2000) provided the size distribution of sulphate, nitrate, ammonium, methanesulphonic acid (MSA) and total organics in the aerosol. In the Q-AMS, the particles are focused into a narrow beam and directed into an oven, which vaporizes the particles. The vaporized components of the particles are ionized by electron impact. The resulting ion fragments are detected with a quadrupole mass spectrometer. A comprehensive table of fragmentation patterns is used to combine the fragments over $300 \mathrm{amu}$ into mass concentrations of the above major compounds. The MSA fragmentation patterns were first implemented in this study and were determined in laboratory experiments (Phinney et al., 2006). In addition to the total sampled particle masses, the composition is also determined as a function of particle size. The particles are sized based on the time it takes for a particle to travel from the inlet to the detection point (time-of-flight mode). This size is measured as a vacuum aerodynamic diameter $\left(D_{v a}\right)$. A detailed description of the design of the Q-AMS, its operation, quantification methods and calibration procedures are given elsewhere (Alfarra et al., 2004; Allan et al., 2003a, b; Jayne et al., 2000; Jimenez et al., 2003).

Also during C-SOLAS, a Micro-Orifice, Uniform-Deposit Impactor (MOUDI) was used to collect particles for major ion analysis using ion chromatography (IC). This was done using Teflon filters on each of the 12 stages of the MOUDI. Despite its name, the MOUDI was operated in a static mode as opposed to rotating mode that gives rise to the uniformdeposit. The static operation was sufficient as the filters were completely extracted in de-ionized water prior to analysis by IC. The MOUDI data in this work was used to determine the contribution from sea salt. The agreement between the Q-AMS measurements and the MOUDI results for chemical species measured using both methods was relatively close (Phinney et al., 2006).

During the Golden Ears study (Shantz et al., 2004), particles were collected on single Teflon filters analyzed by IC for information on the total mass concentrations of inorganic ion constituents (not separated by size) including $\mathrm{Na}^{+}, \mathrm{Cl}^{-}$, $\mathrm{NH}_{4}^{+}, \mathrm{SO}_{4}^{=}, \mathrm{NO}_{3}^{-}$and $\mathrm{K}^{+}$. Particles for analysis of total mass concentrations of particulate organic carbon (OC), black carbon (BC) and water-soluble organic carbon (WSOC) were collected on single Quartz filters. The BC and OC concentrations were determined by a modified NIOSH method using a Sunset Labs Thermal Optical Transmission Instrument (Lee et al., 2003; Sharma et al., 2002). Water-soluble organic carbon (WSOC) was also measured in samples from the quartz filters as described by Shantz et al. (2004).

\subsection{Water uptake: cloud condensation nucleus counter}

A University of Wyoming Model MA100 static thermal gradient cloud condensation nucleus counter $(\mathrm{CCNc})$ was used for the CCN measurements during both studies (Shantz et al., 2003; Snider et al., 2006). Light scattered off the growing droplets within the supersaturated environment of the chamber is detected as a voltage from a photodiode. This voltage is proportional to both the number concentrations and sizes of the growing droplets. For a given supersaturation, the size of the droplets is dependent on their composition, and thus it is difficult to distinguish the effects of number and size from the voltage measurement unless one is relatively constant. For a given particle composition, the difference between the maximum voltage (which is determined when the droplets are at their largest size prior to falling out of the detection region) and the baseline voltage (the signal prior to the exposure of the particles to a water supersaturation in the chamber) is proportional to the number concentration of the droplets. Hereafter, this difference in voltages is referred to as "deltaV".

CCN observations are commonly expressed as the number concentration of particles that activated or $\mathrm{CCN}$ number concentration (e.g. Bilde and Svenningsson, 2004; Cruz and Pandis, 1997; Hegg et al., 2001; Leaitch et al., 1999; Snider et al., 2003; Stroud et al., 2007). One could determine the $\mathrm{CCN}$ number concentration from a calibration constant applied to deltaV (e.g. Leaitch et al., 1999). Due to the limitations discussed above, it is unreasonable to expect to determine accurate $\mathrm{CCN}$ number concentrations using this approach to $\mathrm{CCN}$ measurements in the field where the chemical composition may change over time. Thus, the focus of this work takes the approach of Shantz et al. (2003) and examines the variation in the light scattered by the particles and growing droplets. The rate of change in the scattered light, represented by the time-resolved voltage, is proportional to the growth rate into cloud droplets.

$\mathrm{CCNc}$ supersaturations should be experimentally determined and not assumed to be the theoretical values (Frank et al., 2007). The effective supersaturations (hereafter: $S_{\text {eff }}$ ) within the $\mathrm{CCNc}$ were estimated to be $0.19-0.50 \%$ using nearly monodisperse ammonium sulphate particles generated in the laboratory, as discussed in Shantz et al. (2003). All supersaturations discussed here are based on these calibrations. The evaluation of $S_{\text {eff }}$ results in the largest uncertainty in these measurements. The errors in $S_{\text {eff }}$ are estimated as approximately $\pm 15 \%$. It is difficult to evaluate how this error affects the growth rates from the observations, and so this uncertainty is applied in a model and reflected as the maximum and minimum limits of $S_{\text {eff }}$. 


\section{Model description}

\subsection{Simulations of cloud droplet growth rates in the $\mathrm{CCNc}$}

An adiabatic cloud parcel model (hereafter called the "ACP model") described by Leaitch et al. (1986) was modified to include partially soluble material (Lohmann et al., 2004; Shantz et al., 2003) and to simulate the growth rates in the $\mathrm{CCNc}$ (hereafter referred to as the "CCNc model") (Shantz et al., 2003). The ACP model and the CCNc model differ in how the supersaturation $(S)$ is calculated. In the ACP model, the rate of cooling of the air parcel is balanced by the rate of water uptake to determine $S$ In the CCNc model, $S$ is specified by a transient rise (that occurs in the $\mathrm{CCNc}$ after the flush of particles into the $\mathrm{CCNc}$ chamber) followed by a constant $S$, in an attempt to mimic the variation of $S$ in the chamber. The transient supersaturation, $S_{\text {trans }}$, is defined as: $S_{\text {trans }}=\left(S_{\text {eff }}-S_{\text {start }}\right) \times\left(t / t_{\text {maxss }}\right)+S_{\text {start }}$, where $S_{\text {eff }}$ is the effective supersaturation in the CCNc, $S_{\text {start }}$ is the starting supersaturation at $t=0$ ( $S_{\text {start }}=-0.05$, subsaturated), $t$ is time in the simulation, $t_{\mathrm{maxss}}$ is the time required to reach $S_{\mathrm{eff}}$ (determined from comparisons of simulated growth rates with those measured for pure, nearly monodisperse ammonium sulphate to be $t_{\operatorname{maxss}}=2.25 \mathrm{~s}$ ). When $t<t_{\text {maxss }}$, then $\mathrm{S}=S_{\text {trans }}$. When $t \geq t_{\text {maxss }}$, and $S_{\text {trans }}$ reaches $S_{\text {eff }}$, then $\mathrm{S}=S_{\text {eff }}$ from then onwards in the simulation.

The mass accommodation coefficient $\left(\alpha_{c}\right)$ can have a strong effect on the simulated condensation rate of water, and this is an outstanding uncertainty in quantifying the indirect effect of aerosols on climate forcing. There are a wide range of $\alpha_{c}$-values used in the literature spanning two orders of magnitude, from 0.01 to 1 (e.g. Davidovits et al., 2004; Laaksonen et al., 2005; Marek and Straub, 2001; Mozurkewich, 1986, and the references therein). For cases where an organic film may form on the surface of the cloud droplet, it has been suggested that the value of $\alpha_{c}$ could be as low as $10^{-5}$ (Chuang, 2003; Feingold and Chuang, 2002). Ruehl et al. (2008) determined $\alpha_{c}$ for field measurements (normalized to $\alpha_{c}$ for laboratory ammonium sulphate) and found that $60 \%$ of ambient CCN grew similarly to ammonium sulphate but a number of cases had a low $\alpha_{c}$ compared to ammonium sulphate. We did not have a measurement of the droplet size from this CCNc as was the case for Ruehl et al. (2008) so we were unable to determine $\alpha_{c}$ using their method. Also, $\alpha_{c}$ cannot be determined from the growth rates here, as attempted by Stroud et al. (2007), because of the uncertainties in these CCNc's such as turbulence and edge effects. Consequently, $\alpha_{c}$ is assumed to be unity in all of the present simulations, as suggested in many of the above references. What this means for this study is that although the effect of the organic on water uptake is represented primarily by the dissolution of the organic, any real impact of the organic could alternatively or in some combination be through effects on $\alpha_{c}$ or the surface tension.
For all model runs outlined here, the thermal accommodation coefficient $\left(\alpha_{T}\right)$ is assumed to be 1 . Based on other results (e.g. Chuang, 2006), it is assumed that changing the value for $\alpha_{T}$ will not affect the growth rate significantly. All dry particles are assumed to be spherical. It is also assumed that the compounds present in the particles and droplets do not chemically react with each other.

The output of the model includes information about the droplet size, number concentration and the scattering efficiency of the growing droplets. For direct comparison of the model output to the first five seconds of light scattering off of the droplets from the $\mathrm{CCNc}$ measurements (detected as a voltage), the scattering cross-sectional area of the growing droplets is calculated. The scattering code, previously discussed in Isaac et al. (1986), uses Mie theory with the insoluble core in this double sphere model represented by a small amount of undissolved adipic acid. The refractive indices used for the species of interest are: ammonium sulphate $(1.523,0)$, sulphuric acid $(1.453,0)$, sodium chloride $(1.5442,0)$, organic $(1.45,0)$ and $\mathrm{BC}(1.82,0.74)$.

\subsection{Simulations of organics}

All the organics in the model are assumed to resemble adipic acid in terms of the physical and chemical properties, except for solubility. The latter is varied. This assumption is used because the $\mathrm{CCN}$ and water uptake properties of adipic acid (Table 1) have been widely studied (e.g. Bilde and Svenningsson, 2004; Broekhuizen et al., 2004; Corrigan and Novakov, 1999; Cruz and Pandis, 1997; Ervens et al., 2004; Hori et al., 2003; Joutsensaari et al., 2001; Prenni et al., 2001; Raymond and Pandis, 2002; Shulman et al., 1996) and adipic acid has been observed in the atmosphere (Grosjean et al., 1978; Kawamura and Yasui, 2005; Wang et al., 2006), and because some of its physico-chemical properties lie within a range of values from organic molecules.

The dissolution of the organic in the model depends on its solubility and is based on its equilibrium with the amount of water present on the solution droplets at each time step in a kinetic framework, as described in Shantz et al. (2003). The gradual dissolution of organics increases the mass of the solute in the particle which then contributes to the water activity. Solubility is used here as a surrogate for all potential influences on water uptake, including the surface tension, molecular weight, physical solubility and the potential effects of the organic on $\alpha_{c}$. Since the amount of organic solute is time varying, an "effective solubility" is estimated for the total organic (Sect. 4.2.2 and 4.2.3) that can be a simple measure of the ability of the organic particles to nucleate cloud droplets.

The determination of the hygroscopicity parameter $\kappa$ (Petters and Kreidenweis, 2007: Sect. 5) is also a means of evaluating the water uptake of organic particles, but the application of $\kappa$ does not reflect time varying dissolution (Petters and Kreidenweis, 2008). Solubility and 
Table 1. Summary of properties for adipic acid, a dicarboxylic acid.

\begin{tabular}{|c|c|}
\hline Alternate name & Hexanedioic acid \\
\hline Number of carbons & 6 \\
\hline Molecular formula & $\mathrm{HO}_{2} \mathrm{C}\left(\mathrm{CH}_{2}\right)_{4} \mathrm{CO}_{2} \mathrm{H}$ \\
\hline Molecular weight $\left(\mathrm{g} \mathrm{mol}^{-1}\right)^{\mathrm{a}}$ & 146.14 \\
\hline Index of refraction ${ }^{\mathrm{b}}$ & Real: 1.45 , imaginary: 0 \\
\hline Density $\left(\mathrm{g} \mathrm{cm}^{-3}\right)^{\mathrm{a}}$ & 1.36 \\
\hline Solubility $\left(\mathrm{g} \mathrm{L}^{-1}\right)^{\mathrm{c}}$ & 25 \\
\hline Ionic dissociation factor ${ }^{d}$ & 1 \\
\hline Osmotic coefficient & 1 \\
\hline \multirow[t]{2}{*}{ Surface tension equation in model ${ }^{\mathrm{e}}$} & $\sigma_{s}=\sigma_{w} \times\left(1-b \times \log _{10}\left(\frac{c_{\text {org }}}{a}+1\right)\right)$ \\
\hline & $\begin{array}{l}\sigma_{s}=\text { surface tension of solution at the air-water interface } \\
\sigma_{w}=\text { surface tension of water at the air-water interface } \\
c_{\text {org }}=\text { molarity of organic acids in the water }\end{array}$ \\
\hline Surface tension coefficients ${ }^{\mathrm{f}}$ & $a=0.019, b=0.105$ \\
\hline Growth factor at $95 \% \mathrm{~g}$ & $1.01^{\mathrm{h}}$ \\
\hline
\end{tabular}

${ }^{\mathrm{a}}$ CRC (2004).

$\mathrm{b}$ Index of refraction for succinic acid (CRC, 2004).

${ }^{\mathrm{c}}$ Saxena and Hildemann (1996).

d Bilde and Svenningsson (2004), Broekhuizen et al. (2004), Corrigan and Novakov (1999), Cruz and Pandis (1997).

e Equation from Ervens et al. (2004).

${ }^{\mathrm{f}}$ Ervens et al. (2004) published these coefficients, that had been fitted to the data from Shulman et al. (1996) using the equation above.

$\mathrm{g}$ The growth factor is expressed as a ratio of the wet radius of the droplet over the dry radius of the original particle or CCN.

$\mathrm{h}$ Joutsensaari et al. (2001) and Prenni et al. (2001) state that the growth factor at $90 \%$ relative humidity for adipic acid is 1 . Thus, in the model it was assumed to be 1.01 .

hygroscopicity are different concepts. The physical solubility of a chemical compound is the amount of solute that will dissolve in a fixed volume of water. Often molecules with higher solubilities are good CCN and reasonably hygroscopic, such as ammonium sulphate. Hygroscopicity is the ability of a compound to take up water either through absorption or adsorption. Some organic compounds may exhibit hygroscopic or $\mathrm{CCN}$ behaviour despite having lower physical solubility (Chan et al., 2008; Hartz et al., 2006). The deliquescence relative humidity may be lower and the solubility may be increased for organic mixtures or organics mixed with soluble inorganics (Marcolli et al., 2004).

In this work, each chemical constituent is considered separately and the effects of combining these constituents in a mixture is not treated, except in the way these compounds individually affect the amount of water on the solution droplet. In addition, although the model initiates the particle as a solution droplet, the organic is dissolved only based on its physical solubility in the solution droplet and some of the unique hygroscopic features of certain organic molecules are not treated. Results from the kinetic droplet growth model using variable organic solubilities (Sect. 4) as well as using a $\kappa$ approach (Sect. 5) are compared with the observations of growing droplets.
The dissolution kinetics discussed in Asa-Awuku and Nenes (2007), which is more important at low temperatures, was not accounted for in this work. Also, this work does not take into account the possibility of a lower solubility filmforming organic compound (Feingold and Chuang, 2002; Tervahattu et al., 2002), the effects of which are uncertain (Kanakidou et al., 2005).

\section{Observations and simulations of cloud droplet growth rates in the $\mathrm{CCNc}$}

\subsection{Pacific Ocean - C-SOLAS field study}

The Subarctic Ecosystem Response to Iron Enrichment Study (SERIES), an experiment of the Canadian Surface Ocean and Lower Atmosphere Study (C-SOLAS), took place in the Pacific Ocean in July 2002. The research platform for the atmospheric aerosol measurements was the Mexican oceanographic vessel El Puma. The majority of the measurements were made near Station Papa, an ocean station located in the subarctic northeast Pacific, nearly $1400 \mathrm{~km}$ off shore. All times used in the work for C-SOLAS are in Pacific Daylight Savings Time (i.e. not local time in the ocean, which was $1.5 \mathrm{~h}$ behind PDT). Table 2 outlines the measurements made during this project. Details of the inlets 
Table 2. Summary of the relevant instrumentation from the C-SOLAS field study.

\begin{tabular}{llll}
\hline Measurement & Instrument & Size range & Frequency of measurements \\
\hline Particle size distributions & SMPS & $0.008-0.3 \mu \mathrm{m}$ geometric diameter in 26 size bins & Every 5 min \\
& PCASP & $0.15-3 \mu \mathrm{m}$ geometric diameter in 15 size bins & Every 5 min \\
Particle chemical constituents & MOUDI & $0.03-18.0 \mu \mathrm{m}$ geometric diameter on 12 stages & $4-10 \mathrm{~h}$ per sample \\
& Q-AMS & $0.06-0.6 \mu \mathrm{m}$ vacuum aerodynamic diameter $\left(D_{\mathrm{va}}\right)$ & Every $15 \mathrm{~min}$ \\
Water uptake & CCNc & All particle sizes that would activate in the & Every $\approx 35 \mathrm{~s}$ \\
& & supersaturation range $0.19-0.5 \%$ & \\
\hline
\end{tabular}

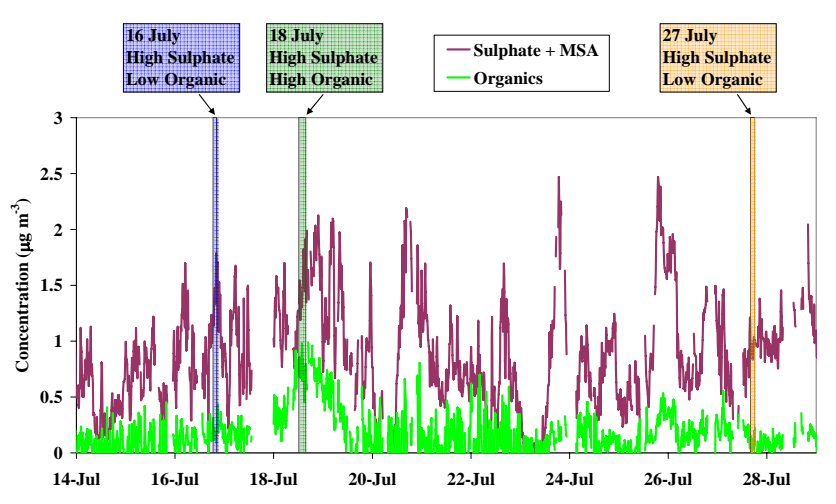

Fig. 1. C-SOLAS time series of Q-AMS mass concentration, with the diesel exhaust spikes removed. Shown are organics and total particulate sulphur (sulphate plus methanesulphonic acid (MSA)). Indicated with arrows are the periods of interest for this work. Each date marker on the $\mathrm{x}$-axis indicates midnight in Pacific Daylight Savings Time (i.e. not local time in the ocean, which was $1.5 \mathrm{~h}$ behind PDT).

and measurements can be found in Marshall et al. (2005), Phinney et al. (2006, 2008).

Over the oceans, sulphate and methanesulphonic acid (MSA) are formed from the oxidation of dimethyl-sulphide $\left(\mathrm{CH}_{3} \mathrm{SCH}_{3}\right)$ (Seinfeld and Pandis, 1998). Natural organic material, other than MSA, is also present in fine particles in marine environments (e.g. O’Dowd et al., 2004; Phinney et al., 2006), and ships contribute primary organic particles as well as $\mathrm{SO}_{2}$ (e.g. Hobbs et al., 2000). In the absence of significant anthropogenic aerosols, either from long-range transport or from ship emissions, the marine aerosol consists primarily of sulphate, MSA and sea salt as well as low concentrations of organics. This was the scenario for most of the C-SOLAS measurements (Phinney et al., 2006).

\subsubsection{C-SOLAS - time series}

The Q-AMS time series of mass concentrations of total particulate sulphur (sulphate+MSA) and total organics for CSOLAS are shown in Fig. 1. Periods of fumigation from the ship's exhaust, during times of mooring, have been removed as described by Phinney et al. (2006). With the exception of the 18-19 July period, sulphur dominates the fine particle aerosol. The ammonium mass concentrations (not shown) were low over the time series (on average, the ammonium to sulphate ratio was 0.2 ) and the sulphate was mostly acidic (Phinney et al., 2006).

For 18-19 July, there was a substantial increase in the organics. The wind speeds were relatively low during this time and the air trajectories looped over the ocean. The Q-AMS mass spectrum for this period resembles a mix of a diesel signature and the background organic (Phinney et al., 2006, 2008). It is believed that in this case the aerosol was impacted by emissions of ship traffic in the region.

Three periods selected for the present study of CCN droplet growth analysis are highlighted in Fig. 1. On 16 July, the fine particle aerosol is made up of $90 \%$ sulphate and MSA and $10 \%$ organic material. On 27 July, the organic fraction was $<10 \%$. The third case, 18 July, is during the peak of the period of highest organic fraction, up to $30 \%$.

\subsubsection{Simulations of 27 July 2002, from C-SOLAS}

The observed particle number distribution for 27 July is shown in Fig. 2a. It is approximated by three lognormal distributions centred at geometric diameters $0.045 \mu \mathrm{m}$ (mode 1 ), $0.16 \mu \mathrm{m}$ (mode 2 ), and $0.65 \mu \mathrm{m}$ (mode 3 ). The chemical mass size distributions from the Q-AMS are compared with the mass size distribution estimated from the SMPS and PCASP in Fig. 2b. The majority of the mass is in sizes $>0.1 \mu \mathrm{m}$, and there is reasonable agreement between the physical and Q-AMS measurements for mode 2.

The Q-AMS measurements lack sufficient sensitivity to resolve the mass in mode 1 , so it is assumed to be $100 \%$ sulphuric acid. Both the Q-AMS and the measurements from the MOUDI indicate the mode 2 particles are composed mostly of acidic sulphate with a smaller amount of MSA. As the Q-AMS total organic is below detection limit in both the time-of-flight and mass measurement modes of the Q-AMS, the organic is assumed to be zero in this case. Assuming that the MSA behaves as sulphate, then mode 2 is modelled as $100 \%$ sulphuric acid. Mode 3 was dominated by sea salt 

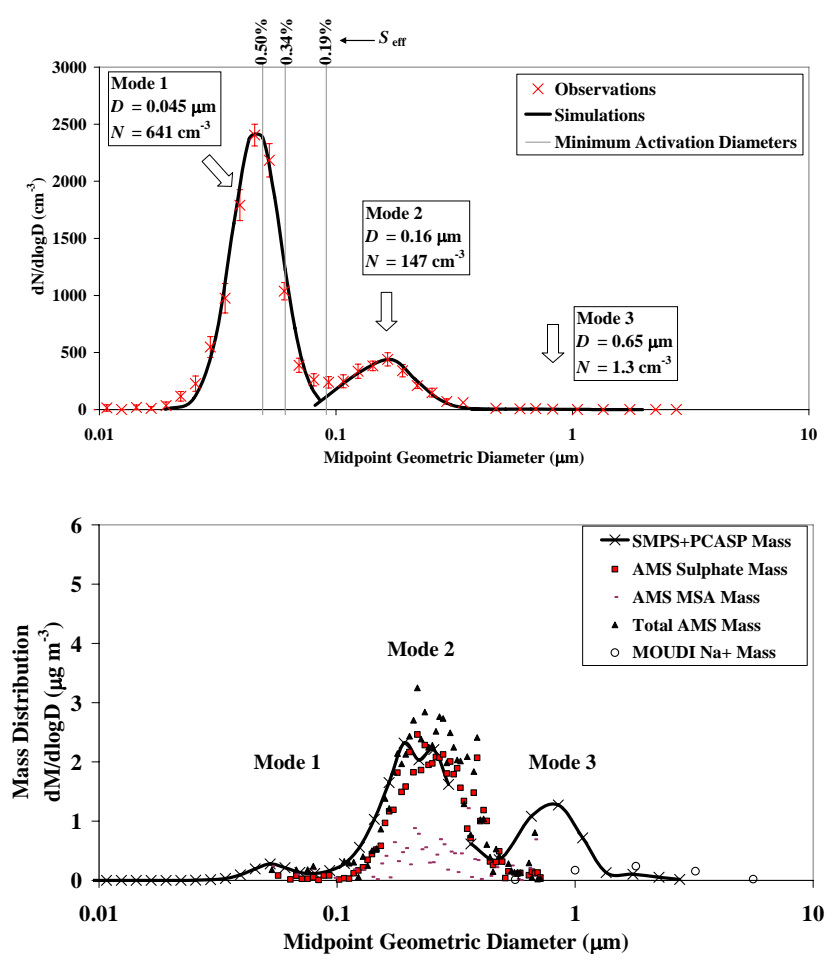

Fig. 2. (a) C-SOLAS 27 July 2002: observed size distribution (from the SMPS and PCASP measurements) and fitted size distribution used in the $\mathrm{CCNc}$ simulations. Indicated are the number median geometric diameter, $D$, and the number concentration, $N$, for the mode. The total number concentration for this period is $789 \mathrm{~cm}^{-3}$. The error bars show the variability in the measurements at a $95 \%$ confidence level $(2 \times$ standard error $)$. The vertical lines correspond with the minimum activation diameter found in the simulations at the effective supersaturations $\left(S_{\text {eff }}\right)$ indicated at the top of the graph (i.e. all particles at this diameter and larger are activated in the simulations). (b) Mass distributions from the MOUDI filter measurements and Q-AMS "time-of-flight" measurements and estimated from the SMPS and PCASP measurements. The SMPS and PCASP masses are estimated from the size distributions (Fig. 2a) using a density approximated from the Q-AMS chemical measurements. The Q-AMS mass size distributions are converted from vacuum aerodynamic diameter $\left(D_{v a}\right)$ to geometric diameter by dividing the $D_{v a}$ by this density.

(Phinney et al., 2006), and it is assumed to consist entirely of $\mathrm{NaCl}$. Table 3 shows the assumptions of the chemical breakdown for all modes for all of the field case studies.

Figure 3 shows the scattering cross-sectional area from the simulations compared with the observed voltage normalized to the base voltage from the CCNc. The scale of the right hand axis has been adjusted to match the simulated growth curves with the observed values. As this is a case of nearly pure polydisperse sulphate, this scaling is used for the remaining cases and provides a reference for the other cases to nearly pure sulphuric acid. The error bars reflect

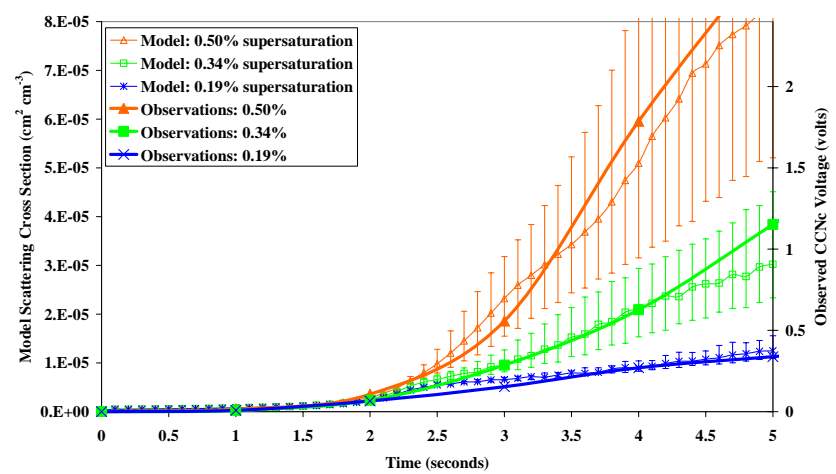

Fig. 3. C-SOLAS 27 July 2002: observations and simulations of $\mathrm{CCNc}$ droplet growth rates. The $\mathrm{x}$-axis is the sample time in seconds as the particles activate and grow into cloud droplets. The observed growth rates at 3 supersaturations (shown as a voltage) from the $\mathrm{CCNc}$ are the thicker lines, corresponding to the $\mathrm{y}$-axis on the right. The $95 \%$ confidence levels $(2 \times$ standard error $)$ of the observed growth curves are $12 \%, 9 \%$ and $7 \%$ of the average for effective supersaturations $\left(S_{\text {eff }}\right)=0.19 \%, 0.34 \%$ and $0.50 \%$, respectively. The other curves with the many symbols and error bars are the modelled curves, on the left y-axis shown as a scattering cross section. These $y$-axes are scaled to match in this case. The error bars are simulations performed at $S_{\text {eff }}= \pm 15 \%$ to reflect the error in the calculated supersaturation.

the model runs performed at $S_{\text {eff }} \pm 15 \%$, giving the maximum and minimum range in $S_{\text {eff }}$ (Sect. 2.3). The minimum activation diameters from the simulations are indicated with vertical lines for the different chamber $S_{\text {eff }}$ (Fig. 2a). At the lowest $S_{\text {eff }}, 0.19 \%$, particles in modes 2 and 3 are activated. For $S_{\text {eff }}=0.34 \%$, a small fraction of particles are activated in mode 1 . At $S_{\text {eff }}=0.50 \%$, just under $50 \%$ of the mode 1 particles are activated. Sensitivity tests with the model indicate that including up to $15 \%$ soluble (solubility $=200 \mathrm{~g} \mathrm{~L}^{-1}$ ) or insoluble (solubility $=10^{-6} \mathrm{~g} \mathrm{~L}^{-1}$ ) organic or changing the sulphuric acid in mode 1 to ammonium bisulphate slightly decreases the growth rate at $S_{\text {eff }}=0.34 \%$ and $0.50 \%$. These same sensitivity tests for mode 2 do not alter the growth rate at all. Overall, because the organic mass was low and these composition sensitivity tests do not modify the results substantially, we believe that this is a good case to use as a reference for the comparisons between the $\mathrm{CCNc}$ observed growth rates and $\mathrm{CCNc}$ model results. The next case study (16 July) will be used to verify this reference case.

\subsubsection{Simulations of 16 July 2002 , from C-SOLAS}

C-SOLAS 16 July has a similar size distribution (Fig. 4a) and chemical composition (Fig. 4b) as 27 July. One difference with 27 July is that 16 July has a $65 \%$ lower number concentration in mode 1 . Note that on 16 July, mode 2 is split into two modes, $2 \mathrm{a}$ at geometric diameter $0.1 \mu \mathrm{m}$ and $2 \mathrm{~b}$ at $0.22 \mu \mathrm{m}$. Both $2 \mathrm{a}$ and $2 \mathrm{~b}$ are assumed to have the same chemical composition. 
Table 3. Assumptions made in the simulations about the size distribution based on the SMPS and PCASP measurements and chemical composition based on Q-AMS and MOUDI measurements (C-SOLAS) and filter measurements (from Golden Ears). Details are shown for each of the 5 case studies and for each mode of the distributions.

\begin{tabular}{|c|c|c|c|}
\hline & $\begin{array}{l}\text { Number Median Geometric } \\
\text { Diameter }(\mu \mathrm{m})\end{array}$ & $\begin{array}{l}\text { Number Concentration } \\
\qquad\left(\mathrm{cm}^{-3}\right)\end{array}$ & Composition Assumption \\
\hline \multicolumn{4}{|c|}{ C-SOLAS 27 July 2002: 16:00-17:30 PDT } \\
\hline Mode 1 & 0.045 & 641 & $\mathrm{H}_{2} \mathrm{SO}_{4}$ \\
\hline Mode 2 & 0.160 & 147 & $\mathrm{H}_{2} \mathrm{SO}_{4}$ \\
\hline Mode 3 & 0.650 & 1.3 & $\mathrm{NaCl}$ \\
\hline Total & & 789 & \\
\hline \multicolumn{4}{|c|}{ C-SOLAS 16 July 2002: 18:45-20:00 PDT } \\
\hline Mode 1 & 0.040 & 435 & $\mathrm{H}_{2} \mathrm{SO}_{4}$ \\
\hline Mode 2a & 0.100 & 36.5 & $10 \%$ organic and $90 \% \mathrm{H}_{2} \mathrm{SO}_{4}$ \\
\hline Mode $2 \mathrm{~b}$ & 0.220 & 112 & $10 \%$ organic and $90 \% \mathrm{H}_{2} \mathrm{SO}_{4}$ \\
\hline Mode 3 & 0.650 & 1.5 & $\mathrm{NaCl}$ \\
\hline Total & & 585 & \\
\hline \multicolumn{4}{|c|}{ C-SOLAS 18 July 2002: 12:15-15:15 PDT } \\
\hline Mode 1a & 0.035 & 146 & $45 \%$ organic and $55 \% \mathrm{H}_{2} \mathrm{SO}_{4}$ \\
\hline Mode $1 \mathrm{~b}$ & 0.080 & 754 & $45 \%$ organic and $55 \% \mathrm{H}_{2} \mathrm{SO}_{4}$ \\
\hline Mode 2 & 0.190 & 133 & $30 \%$ organic and $70 \% \mathrm{H}_{2} \mathrm{SO}_{4}$ \\
\hline Mode 3 & 0.650 & 1.8 & $\mathrm{NaCl}$ \\
\hline Total & & 1035 & \\
\hline \multicolumn{4}{|c|}{ Golden Ears 7 August 2001: 17:00-19:00 PDT } \\
\hline Mode 1 & 0.034 & 11221 & \\
\hline Mode 2 & 0.070 & 2196 & $76 \%$ organic, $4 \%$ black carbon and $20 \%$ ammonium sulphate \\
\hline Mode 3 & 0.360 & 141 & \\
\hline Total & & 13558 & \\
\hline \multicolumn{4}{|c|}{ Golden Ears 11 August 2001: 00:00-01:00 PDT } \\
\hline Mode 1 & 0.050 & 3471 & \\
\hline Mode 2 & 0.090 & 3943 & $85 \%$ organic, $2 \%$ black carbon and $13 \%$ ammonium sulphate \\
\hline Mode 3 & 0.360 & 111 & \\
\hline Total & & 7525 & \\
\hline
\end{tabular}

The Q-AMS measurements for mode 1 are below detection limit. Mode 2 is dominated by acidic sulphate, and organics comprise $10 \%$ of the mode 2 mass, exclusive of MSA. There were no MOUDI measurements on 16 July, so mode 3 is assumed to be $\mathrm{NaCl}$, as consistent with the rest of the study.

The simulated and observed CCN growth rates for 16 July are shown in Fig. 5. With the same right-hand axis scaling as used in Fig. 3, the simulated and observed growth rates compare closely, lending confidence that this scaling properly reflects a sulphate reference for the remaining cases. It does not matter what solubility is assumed for the organic; soluble (solubility $=200 \mathrm{~g} \mathrm{~L}^{-1}$ ) and insoluble (solubility $=10^{-6} \mathrm{~g} \mathrm{~L}^{-1}$ ) organics gave the same results.

\subsubsection{Simulations of 18 July 2002, from C-SOLAS}

The measured and modelled size distributions for 18 July are shown in Fig. 6a, the case with the highest organic mass concentrations. As discussed in Sect. 4.1.1, the mass spectrum of the organic in this case indicates that there was a significant contribution to this organic from diffuse diesel emissions, and the source was possibly from ships crossing the region. The number distribution is represented in the simulations by four modes: mode 1 a centred at geometric diameter $0.035 \mu \mathrm{m}$, mode $1 \mathrm{~b}$ at $0.08 \mu \mathrm{m}$ (hereafter mode $1 \mathrm{a}$ and mode $1 \mathrm{~b}$ will be referred to as "mode 1 "), mode 2 at $0.19 \mu \mathrm{m}$ and mode 3 at $0.65 \mu \mathrm{m}$. The observations of Phinney et al. (2008) show that the geometric diameter of mode $1 \mathrm{~b}$ is larger than the mode diameters on 27 and 16 July due to the sulphate condensing on primary organics from the diesel emissions. 


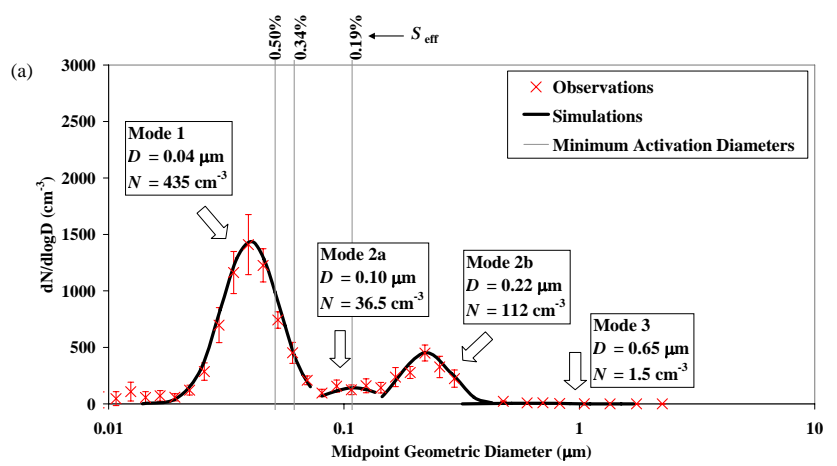

(b)

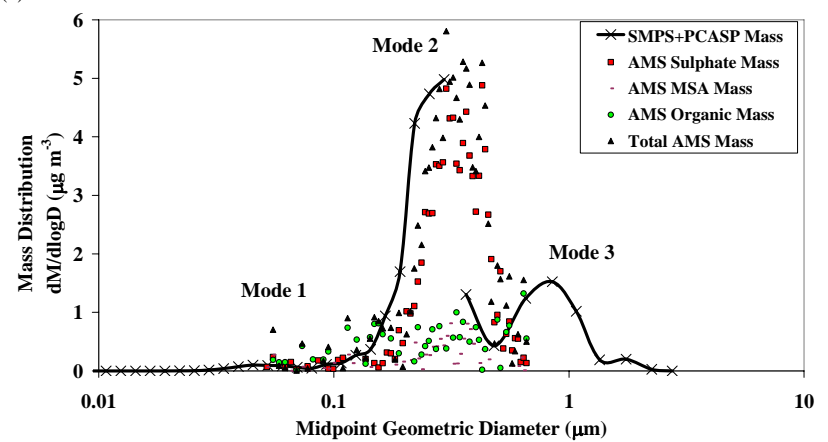

Fig. 4. (a) C-SOLAS 16 July 2002: observed size distribution and fitted size distribution used in the $\mathrm{CCNc}$ simulations. The total number concentration for this period is $585 \mathrm{~cm}^{-3}$. Mode $2 \mathrm{a}$ and mode $2 \mathrm{~b}$ are assumed to have the same chemical composition. (b) Mass distributions from the Q-AMS and estimated from the SMPS and PCASP. There were no MOUDI measurements on 16 July. See Fig. 2 caption for further details.

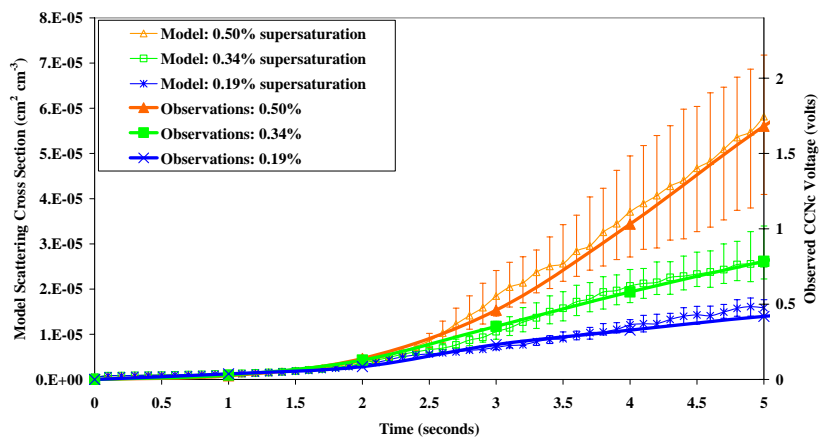

Fig. 5. C-SOLAS 16 July 2002: observations and simulations of $\mathrm{CCNc}$ droplet growth rates. The axis lineup for 27 July (Fig. 3) is tested in this case to give confidence in these comparisons between the observations and simulations. The $95 \%$ confidence levels for the observed growth curves are $15 \%, 10 \%$ and $8 \%$ of the average for $S_{\text {eff }}=0.19 \%, 0.34 \%$ and $0.50 \%$, respectively. See Fig. 3 caption for details.
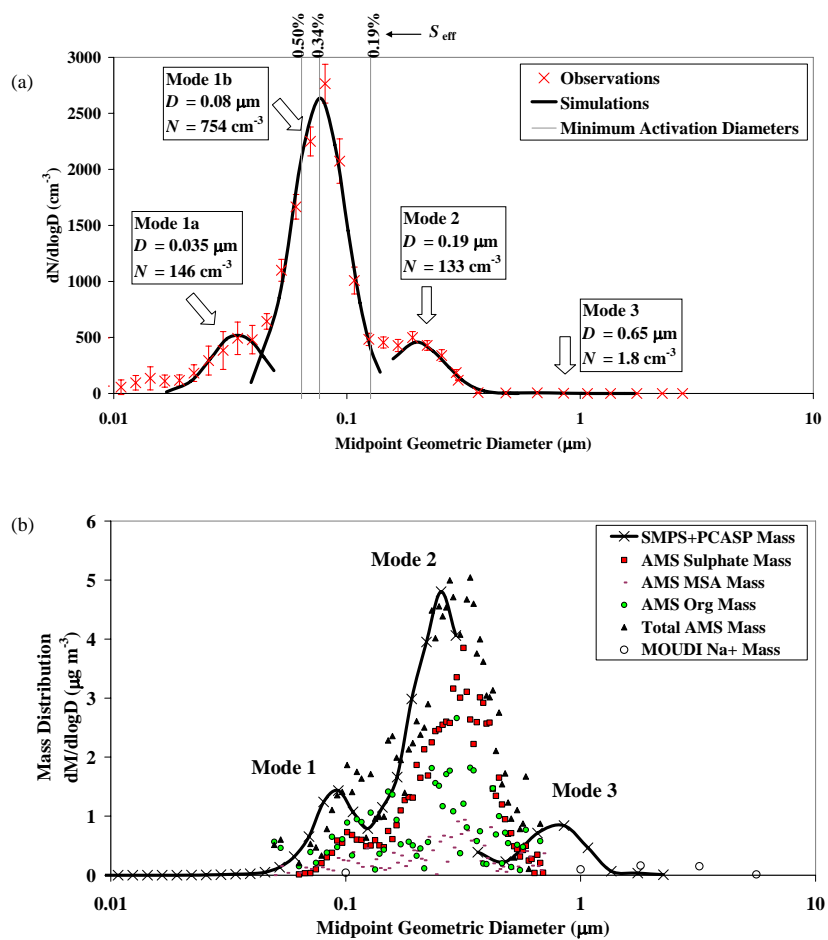

Fig. 6. (a) C-SOLAS 18 July 2002: observed size distribution and fitted size distribution used in the $\mathrm{CCNc}$ simulations. The total number concentration for this period is $1035 \mathrm{~cm}^{-3}$. Mode 1a and mode $1 \mathrm{~b}$ are assumed to have the same chemical composition. The vertical lines show activation for the insoluble organic case. (b) Mass distributions. See Fig. 2 caption for further details.

Figure $6 \mathrm{~b}$ shows the mass distributions. More information about the chemical composition of mode 1 is available from the Q-AMS for 18 July than 27 or 16 July because mode 1 is larger in size and mass concentration. From the Q-AMS measurements, mode 1 is assumed to be composed of $55 \%$ sulphuric acid and $45 \%$ organic, and mode 2 is $70 \%$ sulphuric acid and $30 \%$ organic. These mixtures are assumed to be internally mixed based on the observations described by Phinney et al. (2008). The MOUDI measurements show mode 3 to be a combination of sulphate, sodium nitrate and sodium chloride. Because all three are quite soluble and hygroscopic, the choice is insignificant, and mode 3 is modelled as pure $\mathrm{NaCl}$.

Figure 7a shows the simulations and the $\mathrm{CCNc}$ observations of the droplet growth. The $\mathrm{S}_{\text {eff-error bars are not }}$ shown in this case (for simplicity), but all results fall within that uncertainty. All organics in the distribution are assumed to have the same solubility. The shaded areas encompass the growth rates for assumptions ranging between relatively soluble (solubility $=200 \mathrm{~g} \mathrm{~L}^{-1}$ ) and insoluble organic (solubility $=10^{-6} \mathrm{~g} \mathrm{~L}^{-1}$ ). The soluble case dissolves readily and accumulates more water early on in the simulation; hence the slightly higher growth curves for the soluble case. 
(a)
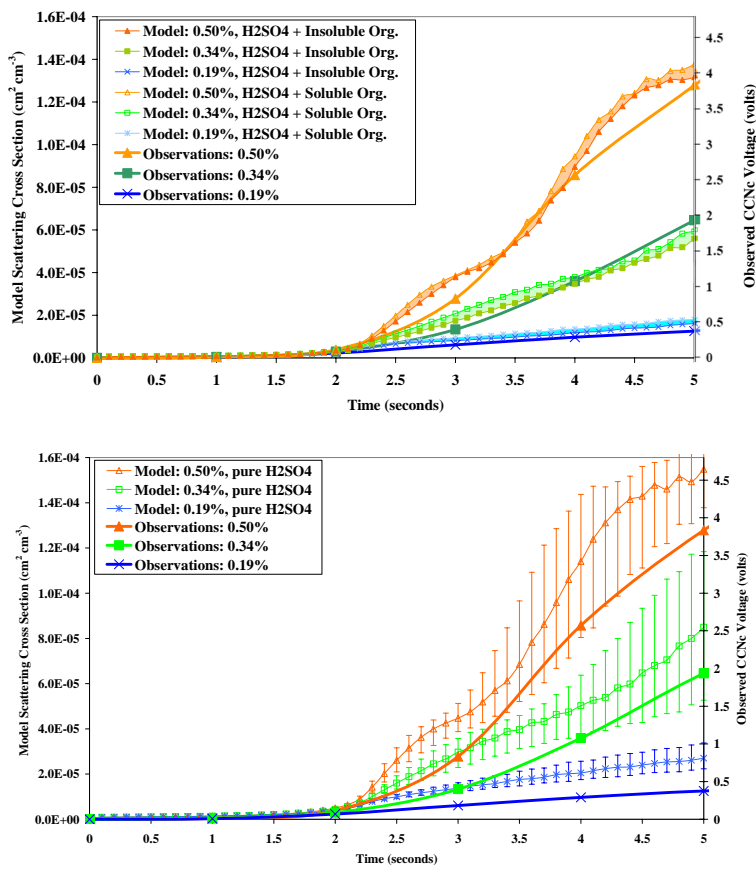

Fig. 7. C-SOLAS 18 July 2002: observations and simulations of $\mathrm{CCNc}$ droplet growth rates for (a) organics included, at two solubilities, with the shaded sections showing the range of solubilities of the organic, from very soluble (top of the shaded sections with solubility $=200 \mathrm{~g} \mathrm{~L}^{-1}$ ) to insoluble (bottom of the shaded sections with solubility $=10^{-6} \mathrm{~g} \mathrm{~L}^{-1}$ ) and (b) the assumption that the entire distribution was pure sulphuric acid (error bars show simulations performed at $S_{\mathrm{eff}}= \pm 15 \%$ ). The $95 \%$ confidence levels for the observed growth curves are $7 \%, 8 \%$ and $5 \%$ of the average for $S_{\text {eff }}=0.19 \%, 0.34 \%$ and $0.50 \%$, respectively. See Fig. 3 caption for more details.

Figure 6a shows the minimum particle diameters activated at the different $\mathrm{S}_{\text {eff-values (the vertical lines) for the insoluble }}$ organic case. The soluble organic case activates at the same or very slightly smaller sizes than for the insoluble case.

At $S_{\text {eff }}=0.19 \%$, all of mode 2 is activating, and there is little difference between the soluble and insoluble organic growth curves because there is only $30 \%$ organic in this mode and a small number concentration (the growth is less sensitive to changes in the chemical composition in such a situation). There is slightly more sensitivity to the choice of soluble and insoluble scenarios at $S_{\text {eff }}=0.34 \%$ and $0.5 \%$, because the activation is occurring in regions of the size distribution where the number concentrations are changing more rapidly with size and the organic fraction is higher. Still the relative differences are very small and the results from this case agree with those of Abdul-Razzak and Ghan (2005), where any solubility assumption is a close enough approximation as long as the organic is not assumed to behave as an inorganic. To illustrate the effect of assuming the organic is equivalent to an inorganic, and because that assumption has been used in some previous closure studies (e.g. Conant et al., 2004), the results of Fig. 7a are reproduced for the case where the entire distribution is assumed to be sulphuric acid (Fig. 7b). In this case, the simulated $\mathrm{CCN}$ scattering cross sections are significantly higher than the corresponding observations, and most of the simulated points lie at the edge of or outside the uncertainty defined by the chamber supersaturation. This result indicates the significant error that arises from assuming the organic portion behaves similarly to the inorganic portion, and underscores the need to treat the components of the aerosol separately.

The results shown in Fig. 7 indicate that the organic reduces the effectiveness of the individual particle as a CCN compared to pure inorganics. However, compared with the cases from 27 and 16 July, considerably more of the mode 1 particles activate on 18 July at the higher $S_{\text {eff-values. This is }}$ why the measured growth rates are higher on 18 July than the other two cases. There is a larger number of particles present at particle sizes that activate at these supersaturations. In this case, the organic appears to have redefined the size distribution of the sulphate. Thus, on 18 July the organic appears to be ineffective at water uptake but it contributes to the formation of a broader, more effective $\mathrm{CCN}$ distribution by redistributing the sulphate.

\subsection{Golden Ears provincial park field study}

The Golden Ears provincial park study was part of the Pacific 2001 field campaign (e.g. Li, 2004). The park (covered predominantly with tall coniferous trees) is on the north slope (203 m elevation) of the Lower Fraser Valley and about $45 \mathrm{~km}$ northeast of Vancouver, British Columbia. Aerosol and trace gas measurements were made in the southern part of the park from 6-11 August 2001. Table 4 summarizes the measurements made during this project that have been discussed previously by Shantz et al. (2004). Note all times mentioned with respect to the Golden Ears study are in local time (i.e. Pacific Daylight Savings Time). The goal of the present study is to examine the cloud-forming properties from this forest aerosol that is also influenced by urban sources.

\subsubsection{Golden Ears study time series}

The particle chemistry from the Golden Ears study was obtained from open filter samples averaged over $4-8 \mathrm{~h}$. A time series of sulphate $\left(\mathrm{SO}_{4}^{=}\right)$and organic carbon (OC) mass concentrations is shown in Fig. 8. The aerosol was dominated by OC through the sampling period, and increasingly towards the end of the period. The organic aerosol is believed to be a mix of primary and secondary organics from both anthropogenic and biogenic sources; sulphate was likely an ammonium salt (Shantz et al., 2004). Figure 8 also shows water-soluble organic carbon (WSOC) concentration. WSOC is $20-60 \%$ of the total OC, which is in the range of what was observed in other studies for polluted, rural and 


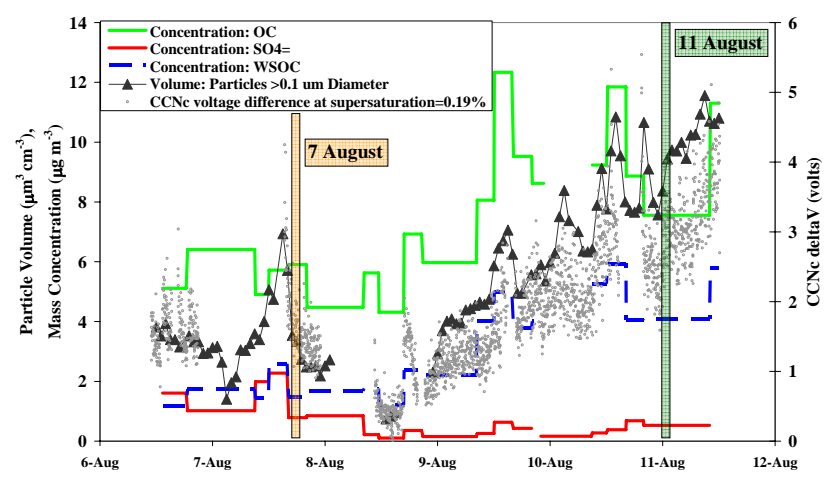

Fig. 8. Golden Ears study time series of filter mass concentrations of organic carbon (OC) and water-soluble organic carbon (WSOC) from the quartz filter samples and sulphate $\left(\mathrm{SO}_{4}=\right)$ from the Teflon filter samples. Also included is the particulate volume from the SMPS and PCASP (for particles $>0.1 \mu \mathrm{m}$ geometric diameter) and the voltage difference (deltaV - see Sect. 2.3 text) from the CCNc at $0.19 \%$ effective supersaturation. Indicated are the periods of interest for this work. Each date marker on the $\mathrm{x}$-axis indicates midnight in Pacific Daylight Savings Time (i.e. local time).

background sites (Carvalho et al., 2003; Decesari et al., 2000, 2001; Saxena and Hildemann, 1996; Zappoli et al., 1999).

The particulate matter volume for particles with geometric diameters $>0.1 \mu \mathrm{m}$ determined from the size distribution measurements is shown in Fig. 8. If we assume a mass density such as $1.0-1.5 \mathrm{~g} \mathrm{~cm}^{-3}$, there is reasonable agreement between the particulate matter volume and the sum of the OC plus sulphate mass concentrations, indicating that most of the OC and sulphate was in the fine particles. The sulphate concentrations at Golden Ears were similar or lower than those measured over the Pacific Ocean.

The CCNc deltaV (proportional to CCN number concentration) at $S_{\text {eff }}=0.19 \%$ switches from being above the particle volume estimate for the first half of the study to being below the particle volume from 9 August onwards (Fig. 8). Although sulphate is low compared to the organic throughout the study, the average sulphate to organic ratio is significantly higher during the period prior to 9 August (0.17) than after 9 August (0.04). The change in the sulphate to organic ratio is a major reason for the change in the correspondence of the $\mathrm{CCN}$ with the particle volume, and it indicates a reduced effectiveness of the organic relative to the sulphate as CCN. To examine this further, two periods are selected representing before and after 9 August. These periods are highlighted in Fig. 8 (afternoon of 7 August and morning of 11 August).
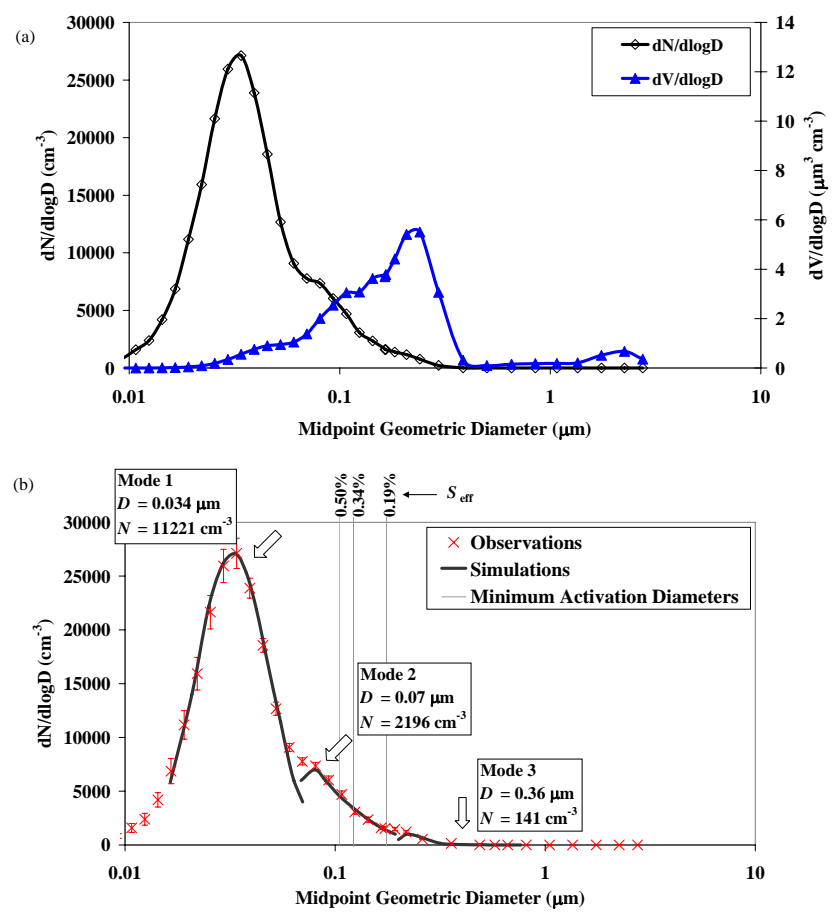

Fig. 9. (a) The Golden Ears study on 7 August 2001: number and volume distributions from SMPS and PCASP. (b) The observed size distribution and fitted size distribution used in the $\mathrm{CCNc}$ simulations. The total number concentration for this period was $13558 \mathrm{~cm}^{-3}$. The vertical lines show activation for the insoluble organic case. See Fig. 2a for further details.

\subsubsection{Simulations of 7 August 2001, from the Golden Ears study}

The particle number and volume distributions for the period selected from 7 August are shown in Fig. 9a. The fitted size distribution used in the $\mathrm{CCNc}$ simulations is matched to these observations using 3 modes as shown in Fig. 9b. There is one dominant number mode at about $0.034 \mu \mathrm{m}$ geometric diameter with a very high number concentration, a shoulder mode near $0.07 \mu \mathrm{m}$, and a large particle mode at $0.36 \mu \mathrm{m}$.

For the purpose of modelling the CCN growth rates in this case, all of the inorganic ions (sulphate, ammonium, nitrate, sodium and chloride) are assumed to be ammonium sulphate. All 3 modes are assumed to have the same composition as each other based on the filter measurements from 7 August: $76 \%$ organic, $4 \%$ BC (an insoluble organic with index of refraction $=(1.82,0.74)$ and density $\left.=2 \mathrm{~g} \mathrm{~cm}^{-3}\right)$ and $20 \%$ ammonium sulphate. Particles are assumed to be internally mixed based on hygroscopic growth measurements at this site (Aklilu and Mozurkewich, 2004; Shantz et al., 2004).

Figure 10 shows the scattering cross-sectional area from the model output compared with the voltage from the $\mathrm{CCNc}$ observations. Absorption by the $\mathrm{BC}$ is included in the 
Table 4. Summary of the relevant instrumentation from the Golden Ears field study.

\begin{tabular}{|c|c|c|c|}
\hline Measurement & Instrument & Size range & $\begin{array}{l}\text { Frequency } \\
\text { of measurements }\end{array}$ \\
\hline \multirow[t]{2}{*}{ Particle size distributions } & SMPS & $0.01-0.2 \mu \mathrm{m}$ geometric diameter in 25 size bins & Every $5 \mathrm{~min}$ \\
\hline & PCASP & $0.15-3 \mu \mathrm{m}$ geometric diameter in 15 size bins & Every $5 \mathrm{~min}$ \\
\hline \multirow[t]{2}{*}{ Particle chemical constituents } & Single Teflon filters & Total mass of all particles that impact & $4-14 \mathrm{~h} /$ sample \\
\hline & Single Quartz filters & Total mass of all particles that impact & 4-14 h/sample \\
\hline Water uptake & $\mathrm{CCNc}$ & $\begin{array}{l}\text { All particle sizes that would activate in the } \\
\text { supersaturation range } 0.19-0.5 \%\end{array}$ & Every $\approx 35 \mathrm{~s}$ \\
\hline
\end{tabular}

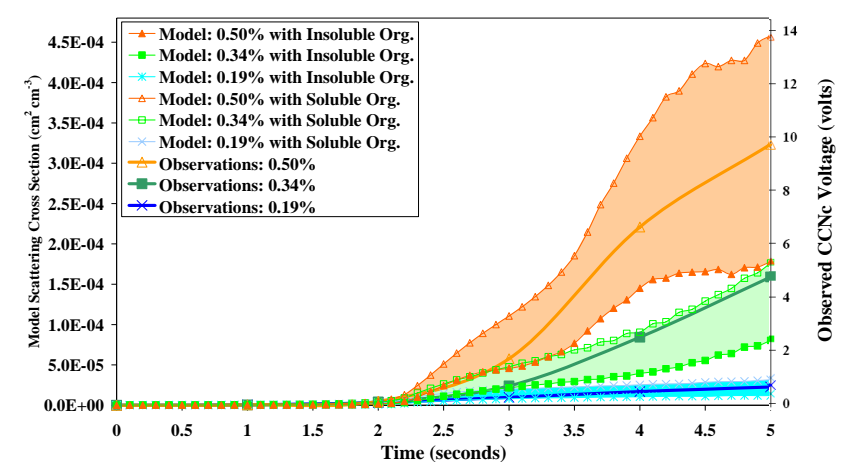

Fig. 10. The Golden Ears study on 7 August 2001: observations and simulations of $\mathrm{CCNc}$ droplet growth rates, showing soluble and insoluble organic scenarios. The $95 \%$ confidence levels are $7 \%$, $3 \%$ and $3 \%$ of the average observed growth curves for $S_{\text {eff }}=0.19 \%$, $0.34 \%$ and $0.50 \%$, respectively. See Figs. 3 and 7 a for details.

calculation; however its influence is negligible because it is present in such small quantities. As for the C-SOLAS 18 July case, the shaded areas encompass the growth rates between relatively soluble and insoluble organic. The vertical lines on Fig. $9 \mathrm{~b}$ show the minimum particle diameters activated for the organics with a solubility of $10^{-6} \mathrm{~g} \mathrm{~L}^{-1}$ and at all $3 S_{\text {eff }}$ 's, these fall within the shoulder mode 2 . The $200 \mathrm{~g} \mathrm{~L}^{-1}$ organic activates at slightly smaller sizes (not shown), but still only activates minimum diameters within mode 2 . Mode 1 does not activate regardless of the organic solubility. (Note that if this distribution was assumed to be pure ammonium sulphate, the minimum activation diameter would be $0.049 \mu \mathrm{m}$ at $S_{\text {eff }}=0.5 \%$ and thus the upper edge of mode 1 would activate.) However, the shoulder mode 2 contains a large number of particles (and mass) that may explain the larger growth rates here than during the C-SOLAS cases. The observed light scattered off the droplets is a function of the number of $\mathrm{CCN}$, the size of $\mathrm{CCN}$ and their chemical composition.

The differences between the modelled soluble (upper curves of shaded sections in Fig. 10) and insoluble (lower curves) organic cases are much larger than for the C-SOLAS 18 July case, indicating a larger range in possibilities with an increased organic fraction in the aerosol. For a highly soluble organic, the observations should match the upper curves. The insoluble organic simulation has only sulphate influencing the droplet growth and if the organic does not contribute at all, the observations will match the lower curves. Since the observed growth rates are much higher than the modelled curves representing insoluble organics and are also substantially higher than those observed for the C-SOLAS cases, which had similar or higher sulphate concentrations, the organic aerosol makes a significant contribution to the water uptake. This may mean that the organic is either moderately soluble or moderately hygroscopic.

Simulated growth rates for an organic with an effective solubility of about $10 \mathrm{~g} \mathrm{~L}^{-1}$ best match the observed growth rates for 7 August. Note that if we change our initial assumptions, this effective solubility may be altered, such as the sulphate and organic may not be distributed equally across all sizes or the organic may have affected the surface tension or mass accommodation coefficient in ways that are not properly referenced in the model.

In these simulations, with ammonium sulphate internally mixed with organics, ammonium sulphate dissolves initially and dominates the droplet growth until more water collects on the droplets allowing the slightly soluble organics to start to dissolve. At that point the organic may also contribute to the droplet growth.

\subsubsection{Simulations of 11 August 2001, from the Golden Ears study}

Figure 11a shows the number and volume distributions for 11 August. The modelled size distribution, represented by 3 modes, is shown in Fig. 11b. Although the total number concentration is less than on 7 August, there are more particles in mode 2 on 11 August than on 7 August and the volume is substantially higher on 11 August. The increased mass is explained by the condensation of secondary organic aerosol as suggested by the gradual increase in particle mass from 9-11 August. Most of the additional material on 11 August is suspected to be due to the oxidation of monoterpenes as measured concentrations of a known 

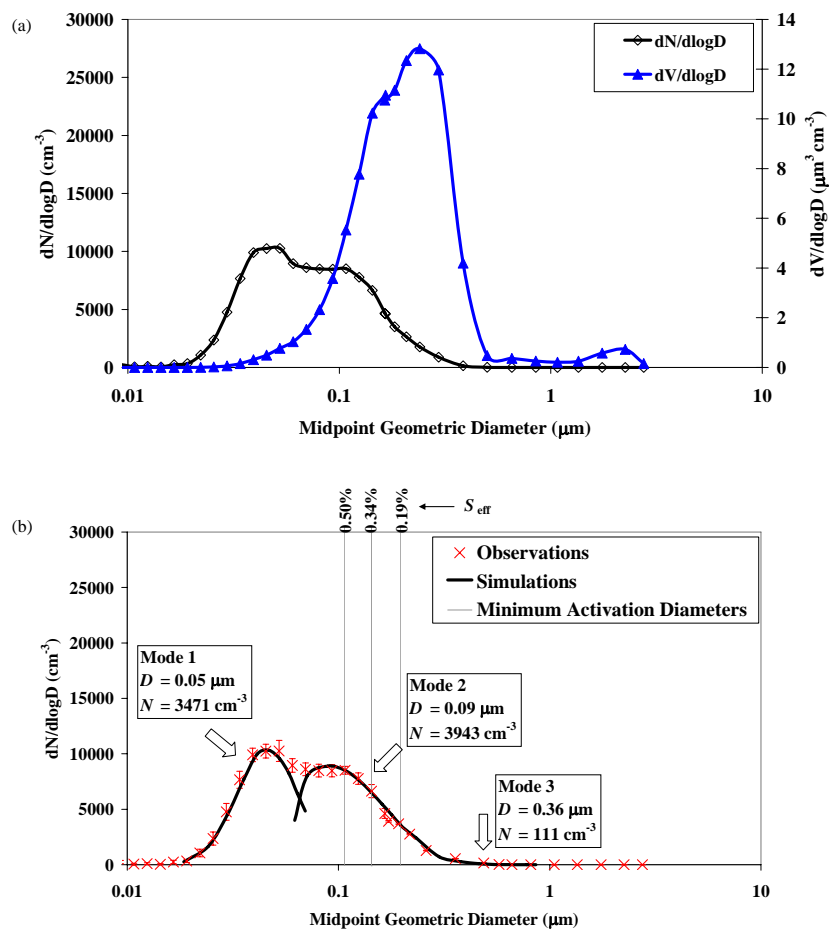

Fig. 11. (a) The Golden Ears study on 11 August 2001: number and volume distributions from SMPS and PCASP. (b) The observed size distribution and fitted size distribution used in the $\mathrm{CCNc}$ simulations. The total number concentration for this period is $7525 \mathrm{~cm}^{-3}$. The vertical lines show activation for the insoluble case. See Fig. 2a for further details.

product of terpene oxidation, cis-pinonic acid, also increased during this period (Cheng et al., 2004; Shantz et al., 2004). Each mode is assumed to have the same composition, an internal mixture of $85 \%$ organic, $2 \% \mathrm{BC}$ and $13 \%$ ammonium sulphate (note that the sum of all inorganic ions is assumed to be ammonium sulphate).

Figure 12 shows the scattering cross-sectional area from the simulations compared with the observations of $\mathrm{CCNc}$ droplet growth rates. The vertical lines in Fig. 11b show the minimum activated diameters at the $3 S_{\text {eff }}$ 's (none of the mode 1 particles activate, even when the organic is assumed to be soluble). The growth rates and the number of particles activated are much greater for 11 August than for any of the previously discussed cases.

At $S_{\text {eff }}=0.50 \%$ the observed growth curves are close to the insoluble curve, suggesting a smaller contribution from the organics to the water uptake on 11 August than 7 August at this supersaturation. The observed growth rates are higher than the modelled insoluble cases at $S_{\text {eff }}=0.34 \%$. The difference between the modelled results at these two $S_{\text {eff-values is }}$ similar to those from 7 August. For $S_{\text {eff }}=0.5 \%$, there may have been competition of water vapour between the particles in the $\mathrm{CCNc}$ at the highest supersaturation. Sensitivity

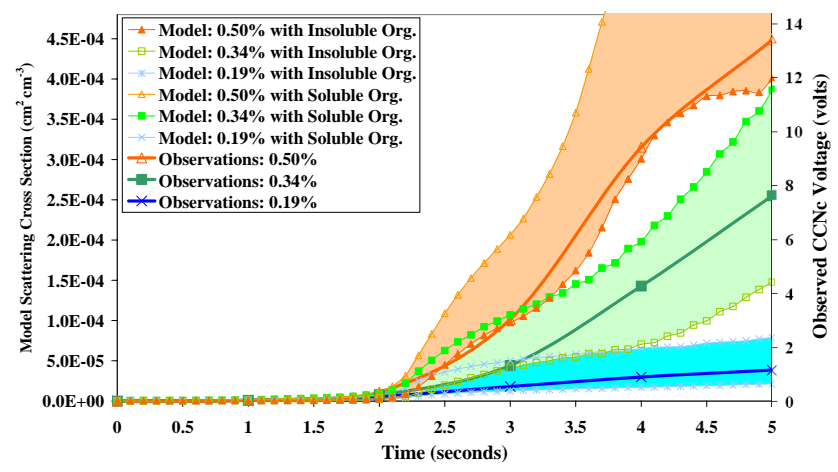

Fig. 12. The Golden Ears study on 11 August 2001: observations and simulations of $\mathrm{CCNc}$ droplet growth rates, showing soluble and insoluble scenarios. The $95 \%$ confidence levels are $8 \%, 6 \%$ and $6 \%$ of the average observed growth curves for $S_{\text {eff }}=0.19 \%, 0.34 \%$ and $0.50 \%$, respectively. See Figs. 3 and 7 a for details.

tests suggest that an aerosol composed of soluble inorganics may deplete the supersaturation substantially but slightly soluble organics do not as they have a smaller solute effect in the Köhler equation (they don't take up water to the same extent as inorganics). If, however, the organics are soluble, competition for water vapour may drive the supersaturation to a lower value especially at $S_{\text {eff }}=0.5 \%$, and therefore would show a lower voltage than it would if competition were not occurring. This may indicate a limitation to the growth rate measurement. Overall, the modelled growth rates best agree with the observations for organics with an effective solubility of $5 \mathrm{~g} \mathrm{~L}^{-1}$, slightly less soluble than 7 August. Keep in mind this is an effective solubility and by changing the initial assumptions, we could find a different value for solubility.

Overall, these results indicate that the organic is less effective as CCN compared to sulphate, but in these situations with relatively low sulphate, the organic particles do act as CCN. Even with lower sulphate masses on 11 August, there is an increase in the deltaV and the scattering cross section as there is an increase in the particle number concentration, and similar to C-SOLAS $18 \mathrm{July}$, it is suspected that the influence of the organic on the sulphate contributes to the increased growth rates. This argument depends on whether the organic coats the sulphate or whether the sulphate is readily available to the water vapour as this model assumes.

\subsubsection{Simulations of WSOC from 7 and 11 August 2001, from Golden Ears}

An alternate set of simulations are also run, using the WSOC measurement to determine the soluble and insoluble fraction of the organic matter. The WSOC/OC fraction is approximately 0.25 on 7 August (Fig. 8). Simulations run with $20 \%$ ammonium sulphate, $20 \%$ organic with $200 \mathrm{~g} \mathrm{~L}^{-1}$ solubility and $60 \%$ insoluble organic based on the WSOC measurements show reasonable agreement between these simulations 
(a)

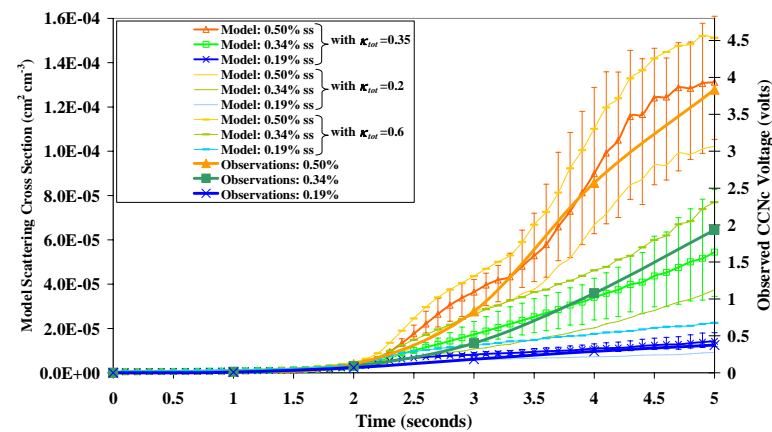

(b)

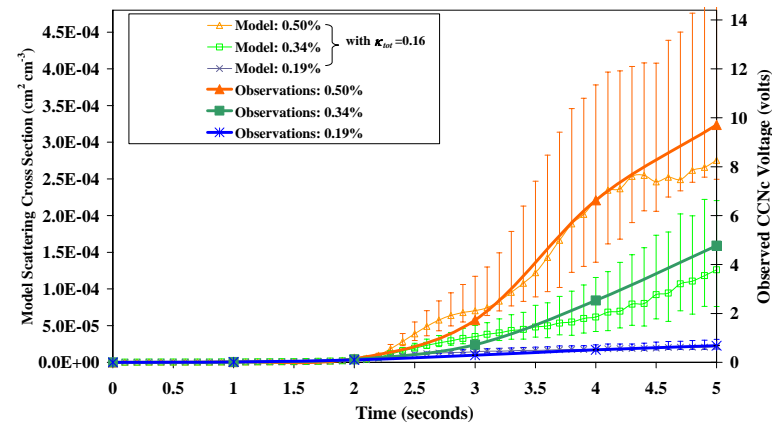

Fig. 13. Observations and simulations of $\mathrm{CCNc}$ droplet growth rates assuming a $\kappa$ tot for the entire distribution for (a) C-SOLAS 18 July and (b) Golden Ears 7 August. The error bars show simulations performed at $S_{\mathrm{eff}}= \pm 15 \%$.

and the observations. The use of a lower solubility (i.e. $<200 \mathrm{~g} \mathrm{~L}^{-1}$ ) worsens the agreement. The WSOC concentration was determined by dissolving the $\mathrm{OC}$ on a filter punch in $5 \mathrm{~mL}$ of water over $10 \mathrm{~min}$ and removing any undissolved material (Shantz et al., 2004). However, WSOC may not be dissolved during the time scales measured by the $\mathrm{CCNc}$ or within the amount of water present on these particles/droplets (Ervens et al., 2007). In the model simulations, the combination of greater sulphate mass in the larger particles and higher supersaturations $(>0.3 \%)$ increases the water on the particle to the point of allowing the organics with solubilities $<2 \mathrm{~g} \mathrm{~L}^{-1}$ to dissolve based on their physical solubility. For lower $S_{\text {eff }}(<0.2 \%)$, the organic solubility needs to be a minimum of $1-20 \mathrm{~g} \mathrm{~L}^{-1}$ to completely dissolve.

Despite the fact that we found a lower overall effective solubility from the simulations for 11 August compared to 7 August, the WSOC/OC fraction is higher on 11 August compared to 7 August (over 50\% - Fig. 8). Simulations (not shown) are run with $13 \%$ ammonium sulphate, $47 \%$ organic with $5 \mathrm{~g} \mathrm{~L}^{-1}$ solubility and $40 \%$ insoluble organic based on the WSOC measurements. Reasonable agreement with the observations is achieved for these assumptions. Organics with solubilities $0.1-5 \mathrm{~g} \mathrm{~L}^{-1}$ would dissolve completely in the largest particle sizes for $S_{\text {eff }}>0.3 \%$. At $S_{\text {eff }}=0.19 \%$, the organic solubility needs to be $3-40 \mathrm{~g} \mathrm{~L}^{-1}$ to dissolve.
There are uncertainties in these measurements such as the long filter sampling time, variations in the chemical composition with respect to size and assumptions about the organic. These simulations are fairly sensitive to the amount of sulphate present and if we decrease the amount of ammonium sulphate, the WSOC solubility would be higher. In the model, it is the solubility of the organic rather than whether it is soluble or not, as determined from WSOC measurements, that affect its role in forming cloud droplets.

\section{Implementing a single parameter representing water uptake $(\kappa)$}

Recently, Petters and Kreidenweis (2007) discussed the hygroscopicity parameter $\kappa$ that encompasses water uptake capabilities (both above and below supersaturation) and simplifies the physical and chemical properties needed for aerosols in cloud microphysical models. Because the majority of organic constituents are unknown and thus properties such as molecular weight and solubility are also unknown, a hygroscopicity parameter is useful in describing the water uptake of aerosols from different sources. A version of the present $\mathrm{CCNc}$ model using $\kappa$ was produced (hereafter " $\kappa$ CCN model") in order to compare estimated total $\kappa$-values $\left(\kappa_{\text {tot }}\right)$ for the five case studies discussed above and to determine the organic $\kappa$-values ( $\kappa_{\text {org }}$ ) from the field measurements. Keep in mind this model does not consider sparingly soluble organics as suggested in Petters and Kreidenweis (2008). Here, $\kappa$ does not change with time or with increasing water content. Also, in the $\kappa$-CCN model, we assume the surface tension of water.

For the nearly pure sulphate case from C-SOLAS (27 July), the best agreement between the $\mathrm{CCNc}$ model and the $\kappa$-CCN model is for $\kappa_{\mathrm{tot}}=0.7$ (see Table 5 for a summary of all $\kappa$-values determined) and a slightly lower value of $\kappa_{\text {tot }}=0.65$ for 16 July due to the small amount of organic. These values are consistent with the $\kappa$-value found for sulphuric acid $(\kappa=0.68-0.74$ for dry diameters $0.03-0.08 \mu \mathrm{m}$, Markus Petters, personal communication), which is lower than the $\kappa=0.9$ mistakenly given in Petters and Kreidenweis (2007).

In Fig. 13a, the results for modelling C-SOLAS 18 July using the $\kappa-\mathrm{CCN}$ model are shown. This case, with a marine aerosol mixed with organic, shows the best agreement with $\kappa_{\mathrm{tot}}=0.35$. The $\kappa_{\mathrm{tot}}$ can be constrained in this case within the supersaturation uncertainty to $0.2-0.6$, as demonstrated in Fig. 13a.

Petters and Kreidenweis (2007) show that for aerosols that consist of a few chemical species, the individual chemical $\kappa$ values can be weighted by the volume fraction to determine the $\kappa_{\text {tot }}$ (using $\kappa_{\mathrm{tot}}=\sum \varepsilon_{i} \kappa_{i}$ where $\varepsilon_{i}$ is the volume fraction and $i$ represents the individual species). Using the measured aerosol composition from the Q-AMS for 18 July (assuming sulphate has $\kappa=0.7$ based on 27 July results) and $\kappa_{\text {tot }}=0.35$, 
then $\kappa_{\text {org }}$ is found to be zero. In other words, for 18 July over the North Pacific Ocean, the organic does not contribute to the water uptake. This organic likely originated as diesel exhaust emissions throughout the region. These results are consistent with hygroscopicity measurements of particles from diesel exhaust, found to not exhibit significant hygroscopic growth (Dua et al., 1999; Weingartner et al., 1997).

For the Golden Ears forest study on 7 August, the best agreement between the observed and modelled growth rates using $\kappa_{\text {tot }}=0.16$ (Fig. 13b). Assuming the ammonium sulphate has a $\kappa=0.61$ (Petters and Kreidenweis, 2007), $\kappa_{\text {org }}$ is estimated as 0.05 . For the Golden Ears study 11 August case, the estimated $\kappa_{\text {tot }}$ is 0.08 , which falls in the range provided by Petters and Kreidenweis (2007) for the oxidation products of monoterpenes (consistent also with $\kappa_{\text {tot }}$ determined by Duplissy et al. (2008) for $\alpha$-pinene oxidation products in a smog chamber). The 11 August $\kappa_{\text {org }}$ is estimated to be 0.02 , lower than the $\kappa_{\text {org }}$ for 7 August. The measurements of water uptake at relative humidities $<100 \%$ that Aklilu and Mozurkewich (2004) made during the Golden Ears study gave values of $\kappa_{\text {tot }}$ (called " $b$ " in their paper) in the range of 0.04 to 0.10 , with most values between 0.05 and 0.07 . These fall within the uncertainty range of the values determined here. The uncertainties in our measurements do not allow the absolute determination of $\kappa_{\text {tot }}$ or $\kappa_{\text {org }}$, but based on the time series, it seems that $\kappa_{\text {tot }}$ or $\kappa_{\text {org }}$ are decreasing over time during the Golden Ears study based on these 2 case studies (consistent with Aklilu and Mozurkewich, 2004) as the organic mass fraction increased.

Smog chamber studies show that particles generated from monoterpene oxidation products were slightly hygroscopic (VanReken et al., 2005; Varutbangkul et al., 2006; Virkkula et al., 1999). Aklilu and Mozurkewich (2004) and Shantz et al. (2004) showed the Golden Ears aerosol was also slightly hygroscopic, similar to the less hygroscopic particles observed in boreal forests (Hameri et al., 2001) and in the Amazon (Rissler et al., 2004; Zhou et al., 2002).

\section{Summary and conclusions}

A cloud condensation nucleus counter $(\mathrm{CCNc})$ is used to investigate the role of organics as $\mathrm{CCN}$ by comparing the measured growth rates of cloud droplets to those simulated using a kinetic model (CCNc model). Five cases of ambient measurements of $\mathrm{CCN}$, particle size distribution and particle chemistry are examined, three from the North Pacific Ocean and two from a forest in British Columbia, Canada. One of the marine cases, for which the aerosol was dominated by sulphate (27 July 2002) is used as a reference for the $\mathrm{CCNc}$ model. This reference case is verified using a second marine case also dominated by sulphate (16 July 2002). In these cases with the fine particle mass $\geq 90 \%$ inorganic, the organics do not contribute to the water uptake and appear to be insoluble.
Table 5. Hygroscopicity parameter $(\kappa)$ values determined for each case study.

\begin{tabular}{llllll}
\hline & \multicolumn{3}{c}{ C-SOLAS } & \multicolumn{2}{c}{ Golden Ears } \\
\cline { 2 - 6 } & $27 \mathrm{Jul}$ & $16 \mathrm{Jul}$ & $18 \mathrm{Jul}$ & $7 \mathrm{Aug}$ & $11 \mathrm{Aug}$ \\
\hline$\kappa_{\text {tot }}$ & 0.7 & 0.65 & 0.35 & 0.16 & 0.08 \\
Range of $\kappa_{\text {tot }}{ }^{\mathrm{a}}$ & $0.4-1.1$ & $0.4-1.0$ & $0.2-0.6$ & $0.09-0.27$ & $0.04-0.17$ \\
$\kappa_{\text {org }}$ & - & 0 & 0 & 0.05 & 0.02 \\
Range of $\kappa_{\text {org }} \mathrm{c}$ & - & $-{ }_{\mathrm{d}}$ & $0-0.5$ & $0.001-0.2$ & $0.001-0.11$ \\
\hline
\end{tabular}

${ }^{\text {a }}$ Simulations are performed for $\kappa_{\text {tot }}$ at $S_{\text {eff }} \pm 15 \%$ to reflect the error in the calculated supersaturation. The ranges of $\kappa$-values are determined by finding $\kappa_{\text {tot }}$ simulations that fall within these error bars.

b The $\kappa_{\text {org }}$ are found by using the measured composition of the aerosol and $\kappa_{\text {tot }}$ and applying the mixing rule $\kappa_{\text {tot }}=\sum \varepsilon_{i} \kappa_{i}$, where $\varepsilon_{i}$ is the volume fraction and $i$ represents each individual chemical constituent.

$\mathrm{c}$ The range of $\kappa_{\mathrm{org}}$ is determined as those that fall within the error bars of $S_{\text {eff }} \pm 15 \%$.

$\mathrm{d}$ Because there was only $10 \%$ organic in this case, it is difficult to determine the range of $\kappa_{\mathrm{org}}$ 's.

The organic fraction is higher in the third marine case (30\% of the total mass - 18 July 2002). Evidence suggests that this aerosol was a mix of somewhat aged ship emissions and marine aerosol. The comparison of the observations and simulations indicates that the sulphate in these aerosol particles was responsible for most of the water uptake. However, the organics influenced the $\mathrm{CCN}$ growth rates by enhancing the number concentration of particles containing sulphate and redistributing the sulphate to larger and more CCN active sizes.

Two forest cases (from Golden Ears Provincial Park) had higher number concentrations, much higher organic mass fractions (80-90\% of the total mass), and similar or smaller sulphate mass concentrations than the marine cases. The observed CCN growth rates from these two cases are much higher than for the marine cases. This is due to an increase in the number concentrations and some influence of the organic material on the water uptake. The best fits of the simulations to the observations were obtained for organics with effective solubilities of $5-10 \mathrm{~g} \mathrm{~L}^{-1}$. This result assumes an accommodation coefficient of unity, a specified surface tension and an organic molecular weight of $146 \mathrm{~g} \mathrm{~mol}^{-1}$. Differences in those three quantities from the modelled values might also contribute to the water uptake.

Values of the hygroscopicity parameter $\kappa$ (Petters and Kreidenweis, 2007) are determined for the five cases using the $\kappa$-CCN model. By comparing the $\kappa$-CCN model results with the observations, $\kappa$-values for the total mixed aerosol $\left(\kappa_{\text {tot }}\right)$ are found. We also found $\kappa$-values for the organic component of the aerosol $\left(\kappa_{\text {org }}\right)$ by assuming the individual chemical $\kappa$-values are volume weighted $\left(\kappa_{\mathrm{tot}}=\sum \varepsilon_{i} \kappa_{i}\right.$ where $\varepsilon_{i}$ is the volume fraction and $i$ represents the individual 
species). For the total aerosol, the Pacific marine $\kappa_{\text {tot }}$-values are $0.35-0.7$ and the organic components are found to be negligible $\left(\kappa_{\mathrm{org}}<0.01\right)$. For the forest aerosol, $\kappa_{\mathrm{tot}}$ is found to be $0.08-0.16$ with $\kappa_{\text {org }}$ of $0.02-0.05$. The observations suggest that $\kappa_{\text {tot }}$ and $\kappa_{\text {org }}$ decreased with time during the Golden Ears study as the aerosol accumulated a larger organic mass. Whether the kinetic approach using solubility for the organic or the approach using a single $\kappa$-value were used, the shape of the growth curves were similar.

Acknowledgements. For the Golden Ears field study (Pacific 2001), the authors would like to than the BC Ministry of Parks for use of the site, and Yayne-Abeba Aklilu, Jeffrey Brook, Armand Gaudenzi, David Halpin, ShaoMeng Li, Nikolina Lincoln and Yen Art Tham for all of their contributions. For the C-SOLAS field study, the authors thank Steve Bacic, David Lavoue, Ulrike Lohmann, Julia Marshall and Sangeeta Sharma as well as the scientists and crew onboard the Mexican El Puma research vessel. The authors also thank Jonathan Abbatt, Rachel Chang, Mark Couture and Wanmin Gong. Nicole Shantz was supported, in part, by an NSERC PGS-B postgraduate research scholarship. Other financial support was provided by C-SOLAS and CFCAS. Many thanks to 3 anonymous reviewers for helpful comments.

Edited by: C. Chan

\section{References}

Abbatt, J. P. D., Broekhuizen, K., and Kumar, P. P.: Cloud condensation nucleus activity of internally mixed ammonium sulfate/organic acid aerosol particles, Atmos. Environ., 39, 47674778, 2005.

Abdul-Razzak, H. and Ghan, S. J.: Influence of slightly soluble organics on aerosol activation, J. Geophys. Res.-Atmos., 110, D06206, doi:10.1029/2004JD005324, 2005.

Aklilu, Y. A. and Mozurkewich, M.: Determination of external and internal mixing of organic and inorganic aerosol components from hygroscopic properties of submicrometer particles during a field study in the Lower Fraser Valley, Aerosol Sci. Technol., 38, 140-154, 2004.

Alfarra, M. R., Coe, H., Allan, J. D., Bower, K. N., Boudries, H., Canagaratna, M. R., Jimenez, J. L., Jayne, J. T., Garforth, A. A., Li, S. M., and Worsnop, D. R.: Characterization of urban and rural organic particulate in the Lower Fraser Valley using two Aerodyne Aerosol Mass Spectrometers, Atmos. Environ., 38, 5745-5758, 2004.

Allan, J. D., Alfarra, M. R., Bower, K. N., Williams, P. I., Gallagher, M. W., Jimenez, J. L., McDonald, A. G., Nemitz, E., Canagaratna, M. R., Jayne, J. T., Coe, H., and Worsnop, D. R.: Quantitative sampling using an Aerodyne aerosol mass spectrometer - 2. Measurements of fine particulate chemical composition in two U.K. cities, J. Geophys. Res.-Atmos., 108, 4091, doi:10.1029/2002JD002359, 2003a.

Allan, J. D., Jimenez, J. L., Williams, P. I., Alfarra, M. R., Bower, K. N., Jayne, J. T., Coe, H., and Worsnop, D. R.: Quantita- tive sampling using an Aerodyne aerosol mass spectrometer - 1 . Techniques of data interpretation and error analysis, J. Geophys. Res.-Atmos., 108, 4090, doi:10.1029/2002JD002358, 2003 b.

Alves, C., Pio, C., and Duarte, A.: Composition of extractable organic matter of air particles from rural and urban Portuguese areas, Atmos. Environ., 35, 5485-5496, 2001.

Anttila, T. and Kerminen, V. M.: Influence of organic compounds on the cloud droplet activation: A model investigation considering the volatility, water solubility, and surface activity of organic matter, J. Geophys. Res.-Atmos., 107, 4662, doi:10.1029/2001JD001482, 2002.

Asa-Awuku, A. and Nenes, A.: Effect of solute dissolution kinetics on cloud droplet formation: Extended Köhler theory, J. Geophys. Res.-Atmos., 112, D22201, doi:10.1029/2005JD006934, 2007.

Bilde, M. and Svenningsson, B.: CCN activation of slightly soluble organics: the importance of small amounts of inorganic salt and particle phase, Tellus B, 56, 128-134, 2004.

Broekhuizen, K., Kumar, P. P., and Abbatt, J. P. D.: Partially soluble organics as cloud condensation nuclei: Role of trace soluble and surface active species, Geophys. Res. Lett., 31, L01107, doi:10.1029/2003GL018203, 2004.

Broekhuizen, K., Chang, R. Y.-W., Leaitch, W. R., Li, S.-M., and Abbatt, J. P. D.: Closure between measured and modeled cloud condensation nuclei $(\mathrm{CCN})$ using size-resolved aerosol compositions in downtown Toronto, Atmos. Chem. Phys., 6, 2513-2524, 2006, http://www.atmos-chem-phys.net/6/2513/2006/.

Cantrell, W., Shaw, G., Cass, G. R., Chowdhury, Z., Hughes, L. S., Prather, K. A., Guazzotti, S. A., and Coffee, K. R.: Closure between aerosol particles and cloud condensation nuclei at Kaashidhoo Climate Observatory, J. Geophys. Res.-Atmos., 106, 28711-28 718, 2001.

Carvalho, A., Pio, C., and Santos, C.: Water-soluble hydroxylated organic compounds in German and Finnish aerosols, Atmos. Environ., 37, 1775-1783, 2003.

Chan, M. N., Kreidenweis, S. M., and Chan, C. K.: Measurements of the hygroscopic and deliquescence properties of organic compounds of different solubilities in water and their relationship with cloud condensation nuclei activities, Environ. Sci. Technol., 42, 3602-3608, 2008.

Chang, R. Y. W., Liu, P. S. K., Leaitch, W. R., and Abbatt, J. P. D.: Comparison between measured and predicted CCN concentrations at Egbert, Ontario: Focus on the organic aerosol fraction at a semi-rural site, Atmos. Environ., 41, 8172-8182, 2007.

Cheng, Y., Li, S. M., Leithead, A., Brickell, P. C., and Leaitch, W. R.: Characterizations of cis-pinonic acid and n-fatty acids on fine aerosols in the Lower Fraser Valley during Pacific 2001 Air Quality Study, Atmos. Environ., 38, 5789-5800, 2004.

Chuang, P. Y.: Measurement of the timescale of hygroscopic growth for atmospheric aerosols, J. Geophys. Res.-Atmos., 108, 4282, doi:10.1029/2002JD002757, 2003.

Chuang, P. Y.: Sensitivity of cloud condensation nuclei activation processes to kinetic parameters, J. Geophys. Res.-Atmos., 111, D09201, doi:10.1029/2005JD006529, 2006.

Conant, W. C., VanReken, T. M., Rissman, T. A., Varutbangkul, V., Jonsson, H. H., Nenes, A., Jimenez, J. L., Delia, A. E., Bahreini, R., Roberts, G. C., Flagan, R. C., and Seinfeld, J. H.: Aerosolcloud drop concentration closure in warm cumulus, J. Geophys. Res.-Atmos., 109, D13204, doi:10.1029/2003JD004324, 2004.

Corrigan, C. E. and Novakov, T.: Cloud condensation nucleus 
activity of organic compounds: a laboratory study, Atmos. Environ., 33, 2661-2668, 1999.

CRC: Handbook of Chemistry and Physics, 85th ed., edited by: Lide, D. R., Chemical Rubber Company (CRC) Press, Boca Raton, Florida, USA, 2004.

Cruz, C. N. and Pandis, S. N.: A study of the ability of pure secondary organic aerosol to act as cloud condensation nuclei, Atmos. Environ., 31, 2205-2214, 1997.

Davidovits, P., Worsnop, D. R., Jayne, J. T., Kolb, C. E., Winkler, P., Vrtala, A., Wagner, P. E., Kulmala, M., Lehtinen, K. E. J., Vesala, T., and Mozurkewich, M.: Mass accommodation coefficient of water vapor on liquid water, Geophys. Res. Lett., 31, L22111, doi:10.1029/2004GL020835, 2004.

Decesari, S., Facchini, M. C., Fuzzi, S., and Tagliavini, E.: Characterization of water-soluble organic compounds in atmospheric aerosol: A new approach, J. Geophys. Res.-Atmos., 105, 14811489,2000

Decesari, S., Facchini, M. C., Matta, E., Lettini, F., Mircea, M., Fuzzi, S., Tagliavini, E., and Putaud, J. P.: Chemical features and seasonal variation of fine aerosol water-soluble organic compounds in the Po Valley, Italy, Atmos. Environ., 35, 3691-3699, 2001.

Dick, W. D.: Estimation of water uptake by organic compounds in submicron aerosols measured during the Southeastern Aerosol and Visibility Study, J. Geophys. Res., 105, 1471-1479, 2000.

Dua, S. K., Hopke, P. K., and Raunemaa, T.: Hygroscopicity of diesel aerosols, Water Air Soil Pollut., 112, 247-257, 1999.

Duplissy, J., Gysel, M., Alfarra, M. R., Dommen, J., Metzger, A., Prevot, A. S. H., Weingartner, E., Laaksonen, A., Raatikainen, T., Good, N., Turner, S. F., McFiggans, G., and Baltensperger, U.: Cloud forming potential of secondary organic aerosol under near atmospheric conditions, Geophys. Res. Lett., 35, L03818, doi:10.1029/2007GL031075, 2008.

Ervens, B., Feingold, G., Clegg, S. L., and Kreidenweis, S. M.: A modeling study of aqueous production of dicarboxylic acids: 2 . Implications for cloud microphysics, J. Geophys. Res.-Atmos., 109, D15206, doi:10.1029/2004JD004575, 2004.

Ervens, B., Cubison, M., Andrews, E., Feingold, G., Ogren, J. A., Jimenez, J. L., DeCarlo, P., and Nenes, A.: Prediction of cloud condensation nucleus number concentration using measurements of aerosol size distributions and composition and light scattering enhancement due to humidity, J. Geophys. Res.-Atmos., 112, D10S32, doi:10.1029/2006JD007426, 2007.

Facchini, M. C., Fuzzi, S., Zappoli, S., Andracchio, A., Gelencser, A., Kiss, G., Krivacsy, Z., Meszaros, E., Hansson, H. C., Alsberg, T., and Zebuhr, Y.: Partitioning of the organic aerosol component between fog droplets and interstitial air, J. Geophys. Res.Atmos., 104, 26 821-26 832, 1999.

Feingold, G. and Chuang, P. Y.: Analysis of the influence of filmforming compounds on droplet growth: Implications for cloud microphysical processes and climate, J. Atmos. Sci., 59, 20062018, 2002.

Fountoukis, C., Nenes, A., Meskhidze, N., Bahreini, R., Conant, W. C., Jonsson, H., Murphy, S., Sorooshian, A., Varutbangkul, V., Brechtel, F., Flagan, R. C., and Seinfeld, J. H.: Aerosol-cloud drop concentration closure for clouds sampled during the International Consortium for Atmospheric Research on Transport and Transformation 2004 campaign, J. Geophys. Res.-Atmos., 112, D10S30, doi:10.1029/2006JD007272, 2007.
Frank, G. P., Dusek, U., and Andreae, M. O.: Technical Note: Characterization of a static thermal-gradient $\mathrm{CCN}$ counter, Atmos. Chem. Phys., 7, 3071-3080, 2007, http://www.atmos-chem-phys.net/7/3071/2007/.

Gao, S., Hegg, D. A., Hobbs, P. V., Kirchstetter, T. W., Magi, B. I., and Sadilek, M.: Water-soluble organic components in aerosols associated with savanna fires in southern Africa: Identification, evolution, and distribution, J. Geophys. Res.-Atmos., 108, 8491, doi:10.1029/2002JD002324, 2003.

Giebl, H., Berner, A., Reischl, G., Puxbaum, H., Kasper-Giebl, A., and Hitzenberger, R.: CCN activation of oxalic and malonic acid test aerosols with the University of Vienna cloud condensation nuclei counter, J. Aerosol. Sci., 33, 1623-1634, 2002.

Graham, B., Guyon, P., Taylor, P. E., Artaxo, P., Maenhaut, W., Glovsky, M. M., Flagan, R. C., and Andreae, M. O.: Organic compounds present in the natural Amazonian aerosol: Characterization by gas chromatography-mass spectrometry, J. Geophys. Res.-Atmos., 108, 4766, doi:10.1029/2003JD003990, 2003.

Grosjean, D., Vancauwenberghe, K., Schmid, J. P., Kelley, P. E., and Pitts, J. N.: Identification of C3-C10 aliphatic dicarboxylicacids in airborne particulate matter, Environ. Sci. Technol., 12, 313-317, 1978.

Gysel, M., Weingartner, E., Nyeki, S., Paulsen, D., Baltensperger, U., Galambos, I., and Kiss, G.: Hygroscopic properties of water-soluble matter and humic-like organics in atmospheric fine aerosol, Atmos. Chem. Phys., 4, 35-50, 2004, http://www.atmos-chem-phys.net/4/35/2004/.

Hameri, K., Vakeva, M., Aalto, P. P., Kulmala, M., Swietlicki, E., Zhou, J., Seidl, W., Becker, E., and O'Dowd, C. D.: Hygroscopic and $\mathrm{CCN}$ properties of aerosol particles in boreal forests, Tellus B, 53, 359-379, 2001.

Hartz, K. E. H., Tischuk, J. E., Chan, M. N., Chan, C. K., Donahue, N. M., and Pandis, S. N.: Cloud condensation nuclei activation of limited solubility organic aerosol, Atmos. Environ., 40, 605617, 2006.

Hegg, D. A., Gao, S., Hoppel, W., Frick, G., Caffrey, P., Leaitch, W. R., Shantz, N., Ambrusko, J., and Albrechcinski, T.: Laboratory studies of the efficiency of selected organic aerosols as CCN, Atmos. Res., 58, 155-166, 2001.

Henning, S., Rosenørn, T., D’ Anna, B., Gola, A. A., Svenningsson, B., and Bilde, M.: Cloud droplet activation and surface tension of mixtures of slightly soluble organics and inorganic salt, Atmos. Chem. Phys., 5, 575-582, 2005, http://www.atmos-chem-phys.net/5/575/2005/.

Hobbs, P. V., Garrett, T. J., Ferek, R. J., Strader, S. R., Hegg, D. A., Frick, G. M., Hoppel, W. A., Gasparovic, R. F., Russell, L. M., Johnson, D. W., O’Dowd, C., Durkee, P. A., Nielsen, K. E., and Innis, G.: Emissions from ships with respect to their effects on clouds, J. Atmos. Sci., 57, 2570-2590, 2000.

Hori, M., Ohta, S., Murao, N., and Yamagata, S.: Activation capability of water soluble organic substances as CCN, J. Aerosol. Sci., 34, 419-448, 2003.

Isaac, G. A., Leaitch, W. R., Strapp, J. W., and Anlauf, K. G.: Summer Aerosol Profiles over Algonquin Park, Canada, Atmos. Environ., 20, 157-172, 1986.

Jayne, J. T., Leard, D. C., Zhang, X. F., Davidovits, P., Smith, K. A., Kolb, C. E., and Worsnop, D. R.: Development of an aerosol mass spectrometer for size and composition analysis of submicron particles, Aerosol Sci. Technol., 33, 49-70, 2000. 
Jimenez, J. L., Jayne, J. T., Shi, Q., Kolb, C. E., Worsnop, D. R., Yourshaw, I., Seinfeld, J. H., Flagan, R. C., Zhang, X. F., Smith, K. A., Morris, J. W., and Davidovits, P.: Ambient aerosol sampling using the Aerodyne Aerosol Mass Spectrometer, J. Geophys. Res.-Atmos., 108, 8425, doi:10.1029/2001JD001213, 2003.

Joutsensaari, J., Vaattovaara, P., Vesterinen, M., Hämeri, K., and Laaksonen, A.: A novel tandem differential mobility analyzer with organic vapor treatment of aerosol particles, Atmos. Chem. Phys., 1, 51-60, 2001, http://www.atmos-chem-phys.net/1/51/2001/.

Kanakidou, M., Seinfeld, J. H., Pandis, S. N., Barnes, I., Dentener, F. J., Facchini, M. C., Van Dingenen, R., Ervens, B., Nenes, A., Nielsen, C. J., Swietlicki, E., Putaud, J. P., Balkanski, Y., Fuzzi, S., Horth, J., Moortgat, G. K., Winterhalter, R., Myhre, C. E. L., Tsigaridis, K., Vignati, E., Stephanou, E. G., and Wilson, J.: Organic aerosol and global climate modelling: a review, Atmos. Chem. Phys., 5, 1053-1123, 2005,

http://www.atmos-chem-phys.net/5/1053/2005/.

Kawamura, K. and Yasui, O.: Diurnal changes in the distribution of dicarboxylic acids, ketocarboxylic acids and dicarbonyls in the urban Tokyo atmosphere, Atmos. Environ., 39, 1945-1960, 2005.

Kreidenweis, S. M., Petters, M. D., and DeMott, P. J.: Deliquescence-controlled activation of organic aerosols, Geophys. Res. Lett., 33, L06801, doi:10.1029/2005GL024863, 2006.

Pradeep Kumar, P., Broekhuizen, K., and Abbatt, J. P. D.: Organic acids as cloud condensation nuclei: Laboratory studies of highly soluble and insoluble species, Atmos. Chem. Phys., 3, 509-520, 2003, http://www.atmos-chem-phys.net/3/509/2003/.

Laaksonen, A., Vesala, T., Kulmala, M., Winkler, P. M., and Wagner, P. E.: Commentary on cloud modelling and the mass accommodation coefficient of water, Atmos. Chem. Phys., 5, 461-464, 2005, http://www.atmos-chem-phys.net/5/461/2005/.

Leaitch, W. R., Strapp, J. W., and Isaac, G. A.: Cloud droplet nucleation and cloud scavenging of aerosol sulphate in polluted atmospheres, Tellus, 38B, 328-344, 1986.

Leaitch, W. R., Bottenheim, J. W., Biesenthal, T. A., Li, S. M., Liu, P. S. K., Asalian, K., Dryfhout-Clark, H., Hopper, F., and Brechtel, F.: A case study of gas-to-particle conversion in an eastern Canadian forest, J. Geophys. Res.-Atmos., 104, 80958111, 1999.

Lee, P. K. H., Brook, J. R., Dabek-Zlotorzynska, E., and Mabury, S. A.: Identification of the major sources contributing to PM2.5 observed in Toronto, Environ. Sci. Technol., 37, 4831-4840, 2003.

Li, S. M.: A concerted effort to understand the ambient particulate matter in the Lower Fraser Valley: the Pacific 2001 Air Quality Study, Atmos. Environ., 38, 5719-5731, 2004.

Lohmann, U., Broekhuizen, K., Leaitch, R., Shantz, N., and Abbatt, J.: How efficient is cloud droplet formation of organic aerosols?, Geophys. Res. Lett., 31, L05108, doi:10.1029/2003GL018999, 2004.

Lowenthal, D. H., Kumar, N., Hand, J., Day, D., Kreidenweis, S., Collett, J., Lee, T., and Ashbaugh, L.: Hygroscopic organic aerosols during BRAVO?, J. Air Waste Manage. Assoc., 53, 1273-1279, 2003.

Marcolli, C., Luo, B. P., and Peter, T.: Mixing of the organic aerosol fractions: Liquids as the thermodynamically stable phases, J. Phys. Chem. A, 108, 2216-2224, 2004.
Marek, R. and Straub, J.: Analysis of the evaporation coefficient and the condensation coefficient of water, Int. J. Heat Mass Transf., 44, 39-53, 2001.

Marshall, J., Lohmann, U., Leaitch, W. R., Shantz, N., Phinney, L., Toom-Sauntry, D., and Sharma, S.: Optical properties of aerosol particles over the northeast Pacific, J. Appl. Meteorol., 44, 12061220, 2005.

Medina, J., Nenes, A., Sotiropoulou, R. E. P., Cottrell, L. D., Ziemba, L. D., Beckman, P. J., and Griffin, R. J.: Cloud condensation nuclei closure during the International Consortium for Atmospheric Research on Transport and Transformation 2004 campaign: Effects of size-resolved composition, J. Geophys. Res.Atmos., 112, D10S31, doi:10.1029/2006JD007588, 2007.

Mircea, M., Facchini, M. C., Decesari, S., Fuzzi, S., and Charlson, R. J.: The influence of the organic aerosol component on CCN supersaturation spectra for different aerosol types, Tellus Ser. BChem. Phys. Meteorol., 54, 74-81, 2002.

Mircea, M., Facchini, M. C., Decesari, S., Cavalli, F., Emblico, L., Fuzzi, S., Vestin, A., Rissler, J., Swietlicki, E., Frank, G., Andreae, M. O., Maenhaut, W., Rudich, Y., and Artaxo, P.: Importance of the organic aerosol fraction for modeling aerosol hygroscopic growth and activation: a case study in the Amazon Basin, Atmos. Chem. Phys., 5, 3111-3126, 2005, http://www.atmos-chem-phys.net/5/3111/2005/.

Mozurkewich, M.: Aerosol Growth and the Condensation Coefficient for Water - a Review, Aerosol Sci. Technol., 5, 223-236, 1986.

O’Dowd, C. D., Facchini, M. C., Cavalli, F., Ceburnis, D., Mircea, M., Decesari, S., Fuzzi, S., Yoon, Y. J., and Putaud, J. P.: Biogenically driven organic contribution to marine aerosol, Nature, 431, 676-680, 2004.

Petters, M. D. and Kreidenweis, S. M.: A single parameter representation of hygroscopic growth and cloud condensation nucleus activity, Atmos. Chem. Phys., 7, 1961-1971, 2007, http://www.atmos-chem-phys.net/7/1961/2007/.

Petters, M. D. and Kreidenweis, S. M.: A single parameter representation of hygroscopic growth and cloud condensation nucleus activity - Part 2: Including solubility, Atmos. Chem. Phys. Discuss., 8, 5939-5955, 2008, http://www.atmos-chem-phys-discuss.net/8/5939/2008/.

Phinney, L., Leaitch, W. R., Lohmann, U., Boudries, H., Worsnop, D. R., Jayne, J. T., Toom-Sauntry, D., Wadleigh, M., Sharma, S., and Shantz, N.: Characterization of the aerosol over the subarctic north east Pacific Ocean, Deep-Sea Res. Pt. II, 53, 2410 2433, 2006.

Phinney, L., Leaitch, W. R., Lohmann, U., Shantz, N. C., and Worsnop, D.: The contributions of DMS and ship emissions to CCN observations over the summertime North Pacific, Atmos. Chem. Phys. Discuss., submitted, 2008.

Prenni, A. J., DeMott, P. J., Kreidenweis, S. M., Sherman, D. E., Russell, L. M., and Ming, Y.: The effects of low molecular weight dicarboxylic acids on cloud formation, J. Phys. Chem. A, 105, 11 240-11 248, 2001.

Raymond, T. M. and Pandis, S. N.: Cloud activation of singlecomponent organic aerosol particles, J. Geophys. Res.-Atmos., 107, 4787-4794, 2002.

Raymond, T. M. and Pandis, S. N.: Formation of cloud droplets by multicomponent organic particles, J. Geophys. Res.-Atmos., 108, 4469, doi:10.1029/2003JD003503, 2003. 
Rissler, J., Swietlicki, E., Zhou, J., Roberts, G., Andreae, M. O., Gatti, L. V., and Artaxo, P.: Physical properties of the submicrometer aerosol over the Amazon rain forest during the wetto-dry season transition - comparison of modeled and measured CCN concentrations, Atmos. Chem. Phys., 4, 2119-2143, 2004, http://www.atmos-chem-phys.net/4/2119/2004/.

Roberts, G. C., Artaxo, P., Zhou, J. C., Swietlicki, E., and Andreae, M. O.: Sensitivity of CCN spectra on chemical and physical properties of aerosol: A case study from the Amazon Basin, J. Geophys. Res.-Atmos., 107, 8070, doi:10.1029/2001JD000583, 2002.

Ruehl, C. R., Chuang, P. Y., and Nenes, A.: How quickly do cloud droplets form on atmospheric particles?, Atmos. Chem. Phys., 8, 1043-1055, 2008,

http://www.atmos-chem-phys.net/8/1043/2008/.

Saxena, P. and Hildemann, L. M.: Water-soluble organics in atmospheric particles: A critical review of the literature and application of thermodynamics to identify candidate compounds, J. Atmos. Chem., 24, 57-109, 1996.

Seinfeld, J. H. and Pandis, S. N.: Atmospheric Chemistry and Physics, John Wiley and Sons Inc., New York, USA, 55-66, 1998.

Shantz, N. C., Leaitch, W. R., and Caffrey, P. F.: Effect of organics of low solubility on the growth rate of cloud droplets, J. Geophys. Res.-Atmos., 108, 4168-4176, 2003.

Shantz, N. C., Aklilu, Y. A., Ivanis, N., Leaitch, W. R., Brickell, P. C., Brook, J. R., Cheng, Y., Halpin, D., Li, S. M., Tham, Y. A., Toom-Sauntry, D., Prenni, A. J., and Graham, L.: Chemical and physical observations of particulate matter at Golden Ears Provincial Park from anthropogenic and biogenic sources, Atmos. Environ., 38, 5849-5860, 2004.

Sharma, S., Brook, J. R., Cachier, H., Chow, J., Gaudenzi, A., and Lu, G.: Light absorption and thermal measurements of black carbon in different regions of Canada, J. Geophys. Res.-Atmos., 107, 4771, doi:10.1029/2002JD002496, 2002.

Shulman, M. L., Jacobson, M. C., Carlson, R. J., Synovec, R. E., and Young, T. E.: Dissolution behavior and surface tension effects of organic compounds in nucleating cloud droplets, Geophys. Res. Lett., 23, 277-280, 1996.

Snider, J. R., Guibert, S., Brenguier, J. L., and Putaud, J. P.: Aerosol activation in marine stratocumulus clouds: 2 . Köhler and parcel theory closure studies, J. Geophys. Res.-Atmos., 108, 8629, doi:10.1029/2002JD002692, 2003.

Snider, J. R., Petters, M. D., Wechsler, P., and Liu, P.: Supersaturation in the Wyoming CCN Instrument, J. Atmos. Ocean. Technol., 23, 1323-1339, 2006.

Stroud, C. A., Nenes, A., Jimenez, J. L., DeCarlo, P. F., Huffman, J. A., Bruintjes, R., Nemitz, E., Delia, A. E., Toohey, D. W., Guenther, A. B., and Nandi, S.: Cloud activating properties of aerosol observed during CELTIC, J. Atmos. Sci., 64, 441-459, 2007.
Tervahattu, H., Hartonen, K., Kerminen, V. M., Kupiainen, K., Aarnio, P., Koskentalo, T., Tuck, A. F., and Vaida, V.: New evidence of an organic layer on marine aerosols, J. Geophys. Res.Atmos., 107, 4053, doi:10.1029/2000JD000282, 2002.

VanReken, T. M., Rissman, T. A., Roberts, G. C., Varutbangkul, V., Jonsson, H. H., Flagan, R. C., and Seinfeld, J. H.: Toward aerosol/cloud condensation nuclei $(\mathrm{CCN})$ closure during CRYSTAL-FACE, J. Geophys. Res.-Atmos., 108, 4633, doi:10.1029/2003JD003582, 2003.

VanReken, T. M., Ng, N. L., Flagan, R. C., and Seinfeld, J. H.: Cloud condensation nucleus activation properties of biogenic secondary organic aerosol, J. Geophys. Res.-Atmos., 110, D07206, doi:10.1029/2004JD005465, 2005.

Varutbangkul, V., Brechtel, F. J., Bahreini, R., Ng, N. L., Keywood, M. D., Kroll, J. H., Flagan, R. C., Seinfeld, J. H., Lee, A., and Goldstein, A. H.: Hygroscopicity of secondary organic aerosols formed by oxidation of cycloalkenes, monoterpenes, sesquiterpenes, and related compounds, Atmos. Chem. Phys., 6, 23672388, 2006, http://www.atmos-chem-phys.net/6/2367/2006/.

Virkkula, A., Van Dingenen, R., Raes, F., and Hjorth, J.: Hygroscopic properties of aerosol formed by oxidation of limonene, alpha-pinene, and beta-pinene, J. Geophys. Res.-Atmos., 104, 3569-3579, 1999.

Wang, H. B., Kawamura, K., and Yamazaki, K.: Water-soluble dicarboxylic acids, ketoacids and dicarbonyls in the atmospheric aerosols over the Southern Ocean and western Pacific Ocean, J. Atmos. Chem., 53, 43-61, 2006.

Weingartner, E., Burtscher, H., and Baltensperger, U.: Hygroscopic properties of carbon and diesel soot particles, Atmos. Environ., 31, 2311-2327, 1997.

Yu, L. E., Shulman, M. L., Kopperud, R., and Hildemann, L. M.: Characterization of organic compounds collected during Southeastern Aerosol and Visibility Study: Water-soluble organic species, Environ. Sci. Technol., 39, 707-715, 2005.

Zappoli, S., Andracchio, A., Fuzzi, S., Facchini, M. C., Gelencser, A., Kiss, G., Krivacsy, Z., Molnar, A., Meszaros, E., Hansson, H. C., Rosman, K., and Zebuhr, Y.: Inorganic, organic and macromolecular components of fine aerosol in different areas of Europe in relation to their water solubility, Atmos. Environ., 33, 27332743, 1999.

Zhou, J., Swietlicki, E., Hansson, H. C., and Artaxo, P.: Submicrometer aerosol particle size distribution and hygroscopic growth measured in the Amazon rain forest during the wet season, J. Geophys. Res., 107, 8055, doi:10.1029/2000JD000203, 2002 . 